Ayrshire methods submitted for publication.doc

\title{
Discriminating faunal assemblages and their palaeoecology based on museum collections: the Carboniferous Hurlet and Index limestones of western Scotland, UK
}

\author{
M. T. DEAN ${ }^{1}$, A. W. OWEN ${ }^{2}$, A. BOWDLER-HiCKS ${ }^{2}$, \& M. C. AKHURST ${ }^{1}$ \\ ${ }^{1}$ British Geological Survey, Murchison House, West Mains Road, Edinburgh EH9 \\ 3LA,UK(email: mtd@bgs.ac.uk) \\ ${ }^{2}$ Department of Geographical and Earth Sciences, University of Glasgow, Gregory \\ Building, Lilybank Gardens, Glasgow G12 8QQ, UK
}

\section{Synopsis}

Historic collections of Scottish Carboniferous macrofossils stored at the British Geological Survey (BGS), Edinburgh include the sole remaining sources of palaeontological data from numerous localities. Exploratory numerical analyses of such collections from the Hurlet and Index limestones of Ayrshire compare favourably with published qualitative assessments of faunal assemblages and palaeoenvironments; demonstrating that old collections can still be used in modern palaeoecological investigations. Macrofaunas from these formations comprise mainly brachiopods and molluscs and were collected from 67 localities that yielded 20 and 94 samples from the Hurlet and Index limestones respectively. Limitations of the presence/absence data were partly overcome by consolidation and restriction of aspects of the data set. Seriation indicates the lithological and environmental gradients of taxa. Cluster analysis reveals groups of samples linked to lithofacies. Principal Components Analysis (PCA) of diversity data derived from the data set in terms of 
Ayrshire methods submitted for publication.doc

numbers of genera in higher taxa highlights differences in gross taxonomic composition in terms of trophic structure, lithology and environment.

Supplementary material: lists of localities, taxa and sample lithologies used in this study are available at http://www.geolsoc.org.uk/SUP00000.

\section{Introduction}

Carboniferous rocks at outcrop underlie much of central Scotland but are predominantly covered by Quaternary deposits, and good exposures of the sedimentary rocks are rare, especially in the economically important coal bearing Namurian and Westphalian successions. However, extensive mining, quarrying and sinking of cored boreholes associated with the exploration and exploitation of coal, ironstone and refractory materials (including limestone) from the late $18^{\text {th }}$ to the mid $20^{\text {th }}$ century yielded a vast amount of detailed palaeontological and stratigraphical knowledge of these rocks (Cameron \& Stephenson 1985; Read et al. 2002; Trewin \& Rollin 2002). Deep mining has ceased but the palaeontological material collected during exploration and exploitation has been retained, often as the sole remaining source of palaeontological data. This is a manifestation of a much wider phenomenon that emphasises the importance of historical palaeontological collections (e.g. see Allmon 2005). The question then arises as to whether these data from the BGS collections are sufficiently complete to render them amenable to palaeoecological analysis.

The use of numerical methods in palaeontology is well established and has been used to address a wide range of palaeontological problems (Harper 1999; Hammer \& 
Ayrshire methods submitted for publication.doc

Harper 2006). Ideally, a systematic sampling programme should be undertaken to provide data for rigorous quantitative analysis of palaeoecological data (Etter 1999). Although the BGS collections were not assembled as part of such a sampling exercise, a set of standard numerical exploratory techniques (see Hammer \& Harper 2006, p. 6) was applied to the macrofaunas in these collections from the Hurlet and Index limestones in western Scotland (Figs 1,2) to determine whether recurrent faunal assemblages could be recognised and reasonable interpretations made in terms of palaeoenvironments and lithofacies. The results of the analysis compare favourably with the published qualitative results of Wilson $(1967 ; 1989)$ whose understanding was founded on a wealth of experience 'based on innumerable observations made over forty years' (Wilson 1989, p. 111).

\section{The Hurlet and Index limestones: a review of the collected palaeontological}

\section{materials}

The Hurlet (Brigantian) and Index (Pendleian) limestones mark the bases of the Lower and Upper Limestone formations respectively (Fig. 2), and have been correlated over most of central Scotland (see Wilson 1967; 1989; Browne et al. 1999). Both limestones occur at the southern margin of the Ayrshire Coalfield (Fig. 1), which is a region of current geological resurvey and 3D computer modelling by the British Geological Survey. The analysis of the macrofaunal assemblages forms part of that work.

The fossils are mainly held in the Biostratigraphy collections in the British Geological Survey office in Edinburgh (see Dean 2002). They were collected from 67 localities (14 for the Hurlet Limestone and 53 for the Index Limestone) over a period of 
Ayrshire methods submitted for publication.doc

approximately 136 years. The sample localities include both borehole and surface exposures. The material from each locality was subdivided by hand specimen lithology into mudstone/claystone (undifferentiated), calcareous mudstone, sandstone, siltstone, calcareous siltstone, limestone, argillaceous limestone, and dolostone. This resulted in 20 macrofaunal samples for the Hurlet Limestone and 94 samples for the Index Limestone. Fossil content was tabulated on a spreadsheet arranged by genera and species within major groups, each determination being made to the highest level of confidence at the localities sampled. For lists of localities, taxa and sample lithologies used in this study see Supplementary material.

The data were compiled over time at the most detailed taxonomic level possible for each locality and so range from records of named species to indeterminate material ascribed only to a phylum. The limitations of the data owing to the gradual acquisition of samples to the collection rather than palaeoecologically focused bulk sampling (e.g. Etter 1999) include:

- Samples differ in dimensions from pieces of core of various diameters to hand specimens of various sizes. It cannot be discounted that at least some of the differences among samples reflect differences in sample dimension, which at present are not quantified but are very variable.

- Specimens from the same locality were not necessarily obtained from the same bed.

- Taxonomic identifications in the database were undertaken by many palaeontologists working on Carboniferous fossils since 1870. Hence they are polythetic and in most instances are not underpinned by systematic monographic studies or ecophenotypic analysis of the material. For older determinations the 
Ayrshire methods submitted for publication.doc

taxonomy may in some cases need updating.

- The collections lack any taphonomic assessment such as the degree to which the fossils were autochthonous or allochthonous.

- Crucially, only presence/absence (binary) data are available and this provides a major limitation on the range of numerical methods that can be applied.

\section{Consolidation and restriction of the data sets}

To overcome limitations of sample size and limited taxonomic overlap between samples in the exploratory analyses, which aim to identify similarities between groups of samples, successive iterations of the analyses were undertaken on increasingly consolidated or restricted versions of the original data.

The species- and genus-level data were consolidated by removing records of indeterminate brachiopods, bivalves and gastropods where named taxa of these groups were recorded from the same sample. If a species was unequivocally identified at any locality in the species-level data set, that name was also applied to all other 'aff.', 'cf.' and '?' determinations applied to that binomen. Next, all taxa restricted to a single locality were excluded so that the analyses of these 'unique taxa excluded' data were based solely on shared occurrences thus reducing considerably the amount of 'noise' in the data. In addition, the genus-level 'consolidated' data were further restricted to higher level taxa (essentially a mixture of phyla and classes), with the number of genera present in each group recorded rather than simple presence or absence. This provides a measure of diversity within the higher taxa and is amenable to ordination using PCA as well as cluster analysis based on quantitative data. 
Ayrshire methods submitted for publication.doc

\section{Numerical methodology}

The consolidated data in binary (presence/absence) format was analysed using the statistical package PAST (PAlaeontological STatistics) (Hammer et al. 2001), which is available on the Internet as freeware, is periodically updated and refined, and is fully supported by an extensive manual.

Four data sets, comprising the Hurlet Limestone species and genera, and Index Limestone species and genera, were transferred into PAST and analysed as described below. Seriation, cluster analysis and to some extent non-metric multidimensional scaling (NMDS) proved suitable techniques for use on the binary data, whilst cluster analysis and PCA were appropriate for the diversity data within high level clades.

Seriation reorganises the original binary data matrix to group shared presences of taxa along a diagonal. Unconstrained optimization enables the ordering of both the taxa and localities to achieve a best fit and the ordering of the localities reflects their position along a palaeoecological, palaeobiogeographical and/or temporal gradient. The fewer the influencing factors (such as water depth, substrate characteristics, salinity and oxygenation), the better the clustering along the diagonal and therefore the higher the fitness criterion computed for the seriation. These fitness criteria are therefore much higher for the consolidated data than for the preliminary analyses, which included taxa unique to any one locality. For example, the species-level seriated matrices gave fitness a criterion of 0.721 for the consolidated data compared with 0.397 for the raw, unconsolidated, data for the Hurlet Limestone 
Ayrshire methods submitted for publication.doc

palaeontological data set and $0.288 \mathrm{cf}$. 0.139 for the equivalent Index limestone data set. When the samples were subdivided by lithology, consolidation generated fitness criteria on the seriations of 0.635 cf. 0.285 and 0.17 cf. 0.11 for the Hurlet and Index limestones respectively. Constraining the seriations, by fixing the ordering of samples of a particular lithology, forces the grouping of other lithologies. For example, constraining the limestone subset in the species-level seriated matrix for the Hurlet Limestone using the consolidated data set with unique taxa excluded reduced the fitness criterion from 0.635 to 0.403 . However, this constrained analysis resulted in the grouping of other lithologies, suggesting ranges of lithofacies tolerance for individual species.

Q-mode analysis was used in the cluster analyses to distinguish groups of samples with similar faunas. Three similarity indices, Dice, Simpson and Raup-Crick, were employed and the clusters joined using the un-weighted pair group average (UPGMA) algorithm. The Dice coefficient was used in the NMDS where persistent patterns in the resultant two dimensional plots of ranked (rather than absolute) difference between samples were taken to reflect genuine structure within the data.

PCA is a widely used eigenvector technique, which operates on a correlation or variance-covariance matrix (Davis 1986) to identify as much of the variation in a set of data and to seek structure within the samples (see Hammer \& Harper 2006). The first principal component is always orientated in the direction of maximum variation in the sample; the second and subsequent components are perpendicular to the first, explaining decreasing amounts of variation. As is common in such analyses, the first two or three eigenvectors in the present study contained most of the sample variation. 
Ayrshire methods submitted for publication.doc

In the first instance, the 'palaeontological' data fields for both the Hurlet and Index limestones were analysed prior to possible links to lithology being explored. The latter involved subdividing the faunal lists from many of the localities in terms of the lithology of the rocks in which each fossil is contained. This increases the information attached to each faunal occurrence but decreases many of the sample sizes and diversities.

\section{Results}

\section{Palaeontological data alone}

Most of the Hurlet Limestone samples are lithologically homogenous and 33\% of species and $36 \%$ of genera in the original palaeontological data set occur at multiple localities. By consolidating the data, the percentage of shared genera increases to 46\%. Excluding taxa restricted to single localities produced minor changes in the order of the localities and higher fitness criteria in the seriated data (e.g. Fig. 3) together with more consistency of clustering among different similarity coefficients used in the cluster analyses (Fig. 4). The last of these is encouraging given the different emphases that these coefficients have in terms of co-occurrences, relative sample size or the mathematical processes involved (e.g. see Hammer \& Harper 2006, pp. 212-213). Three groups of localities were consistently identified in the various seriations and are also recognised by NMDS. Group 1, which also emerges consistently in the cluster analyses (Fig. 4) comprises Carskeoch (locality 12), Daldilling (26), Nethershield (55), River Ayr (Windy Burn) (65) and Windy Burn (67); Group 2 comprises Cairnshalloch Limeworks (9), Captain’s Glen (11), Dailly Station (24), Heronspark Burn (36), Meikleholm Burn (52) and Quarrelhill Burn (57); 
Ayrshire methods submitted for publication.doc

Group 3 comprises Auchmillanhill Bore (1), Captain’s Bridge (10) and River Ayr (Upper Heilar) (64).

These three groups of localities were discriminated purely on the basis of their faunal association but there are some broad links between these faunal associations and lithofacies:

(i) Group 1 is a fauna characteristic of clearer water conditions with a preferrence for a firm substrate. It is linked to a wide range of lithologies, particularly limestone;

(ii) Group 2 is a fauna characteristic of clear water conditions with a preferrence for a soft substrate. It is linked to an association of limestone-dominated lithofacies;

(iii) Group 3 is a low diversity fauna with a preference for muddier water conditions and a soft substrate. It is linked to a siliciclastic lithofacies.

These results closely mimic the seminal semi-quantitative analysis published by Wilson (1989), who presented, in generalised diagrammatic form (Wilson 1989, fig. 9), the occurrence of the most commonly found marine fossils of the Dinantian of central Scotland in relation to the lithology of the host rocks. He related the fossils, at group and genus-level, to the lithology they were found in (mudstones and limestones with increasing or decreasing calcareous and siliciclastic content). From this he deduced their living environments on the continental shelf, which ranged from a nearshore zone with muddy water, to offshore or nearshore zones with clearer water. The parallels between the quantitatively determined groupings of faunas recognised in the BGS collections in the present study and those recognised by 
Ayrshire methods submitted for publication.doc

Wilson with his wealth of field experience demonstrate that geologically significant patterns can be recognised in the historical palaeontological data sets not originally collected for this purpose.

Restricting the genus-level consolidated data to higher taxonomic groups and recording the number of genera present in each group, provided a measure of diversity within the higher taxa (Fig. 5) that was amenable to cluster analysis and PCA (Fig. 6). The grouping of localities evident in the species- and genus-level analyses were not generally preserved in the cluster analyses of the quantitative data, but two large groups of localities were distinguished. These also form non-overlapping portions of the plot of the second and third components of the PCA. Some differentiation of the samples is provided by the third component. These include gastropods at localities 10, 12 and 52 with loadings around zero; anthozoans and bryozoans at localities 65 and 67 with low positive loadings; and nautiloids and others at localities 9, 24 and 57 with higher positive loadings.

In contrast, however, the picture was far from clear for the lithologically more heterogeneous Index Limestone, a thicker depositional unit with a much larger number of samples. No clear palaeoecological patterns emerged from the five associations discriminated in the solely palaeontological data by cluster analysis.

\section{Inclusion of lithological data}

Subdividing the samples on the basis of the lithology containing the fossils provides an explicit link between faunal associations and a potentially very important facet of the palaeoenvironment. 
Ayrshire methods submitted for publication.doc

\section{Hurlet Limestone}

The unconstrained seriations of consolidated data at both species- and genus-level for all taxa from the Hurlet Limestone are very similar and have fairly low fitness criteria of 0.33 and 0.35 respectively. Excluding taxa restricted to any one locality produces a large increase in the fitness criterion to 0.635 and 0.617 respectively (Figs 7, 8). Apart from the distinction of siltstone samples in the genus-level seriation there is no grouping of samples by lithology. Constrained seriation, based on the order of the limestone samples that emerged from an unconstrained analysis of the limestone samples alone produces a grouping of the other lithologies (Figs 9, 10) albeit with lower fitness criteria than the equivalent unconstrained seriations. The seriations show that tolerance ranges of some taxa within the carbonate environments extend into other lithofacies in a systematic way across environmental gradients.

Cluster analyses of species- and genus-level data sets (all taxa and unique taxa excluded) do not reveal consistent patterns. However, recurring groupings of samples emerge from cluster analysis of the numbers of genera within higher taxa. Application of both the Dice and Raup-Crick coefficients to this 'higher taxa' data set show three major clusters (Ht 1-Ht 3), five sub-clusters (Ht 1.1-Ht 3.1), and five close pairings (Ht 1.1.1-Ht 3.1.2) (Fig. 11). The three major clusters can also be recognised on the unconstrained seriation of the whole data set and even more closely in the subset of limestone samples. Again this suggests changing co-occurrences of taxa across an environmental gradient.

The first three components of the PCA represent 93\% of the variation within the 
Ayrshire methods submitted for publication.doc

'higher taxa' data set from the Hurlet Limestone, with 81 \% represented by Principal Component 1 . The main variables along these three principal components are, in turn: (1) brachiopods; (2) bivalves; and (3) crinoids and bryozoans (with algae, foraminifera and crustaceans). The major clusters identified in the cluster analysis (Ht 1, Ht 2 and Ht 3, Fig. 13) can also be recognised on the PCA plots (Fig. 12); their distributions reflecting differences in trophic structure of the faunal associations (and therefore differences in environment). Both the cluster analysis and PCA of the diversity data reveal three major clusters that account for all but 2 of the samples. These groups cut across lithofacies but reflect differences in taxonomic composition and trophic structure.

- Ht 1 includes seven samples. The lithofacies represented are limestone (with dolostone) (57\%) and argillaceous limestone, mudstone/claystone (undifferentiated)/calcareous mudstone, and siltstone (about 14\% each). The fauna includes brachiopods (59\% of all genera recorded within the cluster) with 1-9 genera present in each sample, bivalves (21\%) with 0-3 genera, and crinoid columnals (13\%) with $0-1$ genera.

- Ht 2 includes seven samples. The lithofacies represented are argillaceous limestone (43\%), limestone (29\%) and calcareous sandstone and siltstone (14\% each). The fauna includes mainly brachiopods (93\%) with 1-4 genera, and gastropods (7\%) with $0-1$ genera.

- Ht 3 includes five samples. The lithofacies represented are limestone (80\%) and mudstone/claystone (undifferentiated) (20\%). The fauna includes mainly brachiopods (63\%) with 1-8 genera, crinoids (19\%) with one genus, and bryozoa (11\%) with 0-2 genera. 
Ayrshire methods submitted for publication.doc

\section{Index Limestone}

The fitness criteria for the unconstrained seriations of the species- $(0.06)$ and genus(0.11) level data sets for all taxa and even for the data with the unique taxa excluded are very low (species 0.17 and genera 0.20 ), and none show grouping of samples from similar lithologies. Constraining the genus-level seriation by the ordering determined for the limestone samples alone results in most of the other lithologies grouping together, but the fitness criterion is extremely low $(0.10)$ and there is no clear relationship between lithofacies and faunas. However, the broad grouping of the lithologies suggests that some taxa were distributed along environmental gradients within the carbonate depositional setting and extended outside it into other sedimentary environments in a non-random way.

The results of cluster analyses of all the species- and genus-level data sets do not show any consistent groupings. However, cluster analysis of the higher taxa 'diversity’ data set using both the Dice and Raup-Crick coefficients shows eight nested clusters (Ix 1.1-Ix 2.6) of three or more samples (Fig. 13) within two major clusters (Ix 1 and Ix 2), broadly reflecting differences in lithology. This suggests there is a crude link between lithology and the diversity and distribution of genera among the higher taxa.

Most of the variation in the 'higher taxa' data set for the Index Limestone is expressed by components 1 and 2 of the PCA which together comprise almost $89 \%$ of the variance in the data; the third component accounts for $4 \%$. The main loadings on these components are, sequentially: (1) brachiopods and bivalves (strong positive loading); (2) brachiopods (strong negative loading); and (3) gastropods. The 
Ayrshire methods submitted for publication.doc

major and nested clusters discerned in the cluster analysis can also be distinguished to some extent on the PCA plots (Fig. 14). In general, the most calcareous mudstone faunas in the Index Limestone are mainly included in major cluster Ix 1 and are of low diversity with brachiopods the dominant or sole component and molluscs generally absent. Sandstones and especially siltstones are mainly included major cluster Ix 2 and have moderate to high diversities of brachiopods and bivalves with gastropods present in some cases.

\section{Palaeoecological and palaeoenvironmental interpretation of the structure}

\section{identified in the collections}

\section{Hurlet Limestone}

The lithofacies and environmental gradients of taxa selected from the genus-level constrained seriation of the unique taxa excluded data set are shown in Figure 15. These taxa are included in the three faunal groups previously identified, and their palaeoecology accords with the interpretations of Wilson (1989).

The dominant taxa, general trophic structure and palaeoenvironment occupied by the groups of samples identified by cluster analysis of the higher taxa data set (Fig. 11) and to a large extent recognisable in the PCA plots (Fig. 12) can be summarised as follows:

- Ht 1 contains brachiopods and bivalves and, in most samples, crinoid columnals. The epifaunal brachiopods will have colonised a range of substrates depending upon whether they were pedunculate or free lying, but the bivalves are considered to represent infauna with a preference for more muddy substrates. The lithologies of the samples suggest that this major 
Ayrshire methods submitted for publication.doc

cluster represents a great range of environments, but mainly clear water in the off- or nearshore zones.

- Ht 2 is dominated by brachiopods indicating a range of substrates depending upon whether they were semi-infaunal, pedunculate or free lying. Gastropods also occur, which may have preferred to graze or plough carbonate mud.

- Ht 3 is of epifaunal forms, mainly brachiopods and crinoids most of which will have flourished on firmer substrates.

\section{Index Limestone}

Seriation of all the consolidated genus-level data with the samples constrained to the order obtained by seriating the limestone samples alone suggests that the faunal gradients within the carbonate depositional environments can be extended into increasingly coarse siliciclastic sediments. Figures 16 and 17 show this for taxa that have, respectively, an extensive and a limited range within the carbonate environment.

The major clusters and their sub-clusters identified in the cluster analysis for the higher taxa data set are at least partially recognised on the ordination of samples on the PCA and show links between faunal associations and lithologies that reflect the exploitation of subtly different environments. A detailed analysis of the composition and trophic structure of the clusters will form part of a separate study; suffice it to note here that:

Ix 1 is dominated by brachiopods and includes mainly calcareous lithofacies. The limestone lithologies indicate clearer water, the offshore or nearshore zones, firmer substrates, and dominant epifaunal forms. The slightly calcareous mudstone and 
Ayrshire methods submitted for publication.doc

mudstone/claystone (undifferentiated) lithologies provide evidence of the intermediate to muddy nearshore zones, the latter especially with less firm substrates dominated by infaunal forms. The siltstone lithology of a single sample provides almost insignificant evidence of a zone considered to represent river sediment influx.

Ix 2 is dominated by brachiopods and various molluscs. It includes mainly calcareous lithofacies, but with a significant proportion of siliciclastic sedimentary rocks. The limestone, and slightly calcareous mudstone and mudstone/claystone (undifferentiated) lithologies are indicative of the same palaeoenvironments and faunal associations as for Ix 1 . The siltstone and sandstone lithologies show a siliciclastic environment in what is considered to represent a zone of river sediment influx.

\section{Conclusions}

- Exploratory numerical techniques can be successfully applied to historical palaeontological collections (not originally intended to investigate palaeoecology) to distinguish palaeoecologically meaningful faunal associations and their palaeoenvironmental setting.

- Records of sample locality and lithology ('environmental data') and fossil content (described by major fossil groups, genera and species) can be used; the limitations of sample size, taxonomic overlap and solely binary (presence or absence) data being minimised by excluding all 'one off' occurrences of fossil taxa and analysing increasingly consolidated or restricted versions of the original information.

- Seriation, cluster analysis and NMDS are suitable techniques for use on 
Ayrshire methods submitted for publication.doc

binary data, whilst the distribution of genera within higher taxonomic groups can be used as a proxy for abundance data to distinguish meaningful faunal associations using cluster analysis and PCA.

- Seriation can be used to indicate the lithological and environmental gradients of some taxa. Cluster analysis can reveal groups of samples, linking lithology and the diversity and distribution of taxa. PCA can explain the distribution of the clusters in terms of differences in taxonomic composition, trophic structure, lithology and environment.

- Quantitative analysis of the historical BGS collections from the Hurlet and Index limestones confirms the relationship between lithofacies and palaeoenvironment inferred by Wilson (1989) and enables the recognition of more subtle patterns not identifiable by qualitative means.

- The success of this study unlocks the potential for palaeoecological interpretation by multivariate numerical analysis of historical collections not originally intended to investigate palaeoecology. An example of such a collection is that of the BGS, where a vast resource, originally collected for biostratigraphy, now awaits renaissance in palaeoecology.

\section{Acknowledgements}

A. W. Owen and A. Bowdler-Hicks are grateful for funding from the British Geological Survey to undertake the exploration of numerical techniques on the Hurlet and Index limestone collections. Publication is by permission of the Director, British Geological Survey (NERC). 
Ayrshire methods submitted for publication.doc

\section{References}

ALLMON, W.D. 2005. The importance of museum collections in paleobiology. Paleobiology, 31, 1-5.

BROWNE, M.A.E., DEAN, M.T., HALL, I.H.S., MONRO, S.K. \& CHISHOLM, J.I. 1999. A lithostratigraphical framework for the Carboniferous rocks of the Midland Valley of Scotland (Version 2). British Geological Survey Research Report, RR/99/07.

CAMERON, I.B. \& STEPHENSON, D. 1985. British Regional Geology: the Midland Valley of Scotland ( $3^{\text {rd }}$ edition). HMSO for British Geological Survey, London. DAVIS, J.C. 1986. Statistics and Data Analysis in Geology. John Wiley \& Sons, New York.

DEAN, M.T. 2002. The Carboniferous macropalaeontology and biostratigraphy of Ayr and Mauchline (Scotland Sheet 14). British Geological Survey Internal Report, IR/02/006.

ETTER, W. 1999. Community Analysis. In Harper, D.A.T. (ed.) Numerical Palaeobiology. John Wiley \& Sons, Chichester, 285-360.

HAMMER, Ø. \& HARPER, D.A.T. 2006. Paleontological Data Analysis. Blackwell Publishing, Oxford.

HAMMER, Ø., HARPER, D.A.T. \& RYAN, P.D. 2001. PAST: palaeontological 
Ayrshire methods submitted for publication.doc

statistics software package for education and data analysis. Palaeontologia Electronica, 4, Part 1, Article 4.

HARPER, D.A.T. 1999. Preface. In Harper, D.A.T. (ed.) Numerical Palaeobiology. John Wiley \& Sons, Chichester, ix-X.

HOLLIDAY, D.W. \& MOLYNEUX, S.G. 2006. Editorial statement: new official names for the subsystems, series and stages of the Carboniferous System - some guidance for contributors to the Proceedings. Proceedings of the Yorkshire Geological Society, 56, 57-58.

READ, W.A., BROWNE, M.A.E., STEPHENSON, D. \& UPTON, B.G.J. 2002.

Carboniferous. In Trewin, N. H. (ed.) The Geology of Scotland (4 ${ }^{\text {th }}$ edition).

Geological Society, London, 251-299.

TREWIN, N.H. \& ROLLIN, K.E. 2002. Geological history and structure of Scotland. In Trewin, N.H. (ed.) The Geology of Scotland (4 ${ }^{\text {th }}$ edition). Geological Society, London, 1-25.

WILSON, R.B. 1967. A study of some Namurian marine faunas of central Scotland. Transactions of the Royal Society of Edinburgh, 66, 445-490.

WILSON, R.B. 1989. A study of the Dinantian marine macrofossils of central Scotland. Transactions of the Royal Society of Edinburgh: Earth Sciences, 80, 91126. 
Ayrshire methods submitted for publication.doc

Figure captions:

FIG. 1. The geology of the Ayrshire Coalfield Basin including the crop of the Hurlet and Index limestones and the sample localities. Graticule is British National Grid. For full details of the sample localities see Supplementary material.

FIG. 2. Stratigraphical framework for the Ayrshire Coalfield Basin including up-todate lithostratigraphical nomenclature. Based on Browne et al. (1999, table 1); Holliday \& Molyneux (2006, fig. 1).

FIG. 3. Hurlet Limestone. Species-level seriated matrix for the unique taxa excluded data set. Fitness criterion $=0.721$. For locality details see Supplementary material .

FIG. 4. Hurlet Limestone. Species-level cluster analyses for the unique taxa excluded data set, using the Dice, Simpson, and Raup-Crick coefficients.

FIG. 5. Hurlet Limestone. Data matrix for the diversity analysis showing the higher taxa, localities and numbers of genera within each taxon at those localities. For locality details see Supplementary material.

FIG. 6. Hurlet Limestone. Plot of first and second components in the PCA of the number of genera in the higher taxa. The numbered localities are listed in Figure 4. Contours delimit the number of higher taxa in each group.

FIG. 7. Hurlet Limestone. Species-level seriated matrix for the unique taxa excluded 
Ayrshire methods submitted for publication.doc

data set. Fitness criterion $=0.635$. Lithological abbreviations: CMdst $=$ calcareous mudstone; CSlst $=$ calcareous siltstone; Dst $=$ dolostone; Lst $=$ limestone; Mdst = mudstone/claystone (undifferentiated); MLst = argillaceous limestone; Slst = siltstone; Sst = sandstone. For sample and taxonomic details see Supplementary material.

FIG. 8. Hurlet Limestone. Genus-level unconstrained seriated matrix for the unique taxa excluded data set. Fitness criterion $=0.617$. For lithological abbreviations see Figure 7. For sample and taxonomic details see Supplementary material.

FIG. 9. Hurlet Limestone. Species-level seriation to observe lithological groupings of taxa using all samples constrained, for the unique taxa excluded data set. Fitness criterion $=0.403$. For lithological abbreviations see Figure 7. For sample and taxonomic details see Supplementary material.

FIG. 10. Hurlet Limestone. Genus-level seriation to observe lithological groupings of taxa using all samples constrained, for the unique taxa excluded data set. Fitness criterion $=0.426$. For lithological abbreviations see Figure 7. For sample and taxonomic details see Supplementary material.

FIG. 11. Hurlet Limestone. Cluster analysis for the higher taxa data set used in the diversity analysis, using the Raup-Crick coefficient. For sample details see Supplementary material. Ht 1-3: major clusters of samples; Ht 1.1-3.1: nested clusters of samples; Ht 1.1.1-3.1.2: close pairings of localities. 
Ayrshire methods submitted for publication.doc

FIG. 12. Hurlet Limestone. Plot of: (a) the first and second principal components, and (b) the second and third principal components in the PCA of the numbers of genera present in higher taxa showing the fields occupied by samples belonging to the three major clusters (Ht 1-3) identified in Figure 11. For sample details see Supplementary material.

FIG. 13. Index Limestone. Cluster analysis for the higher taxa data set used in the diversity analysis, using the Raup-Crick coefficient. For sample details see Supplementary material. Ix 1-2: major clusters of samples; Ix 1.1-2.6: nested clusters of samples. Note that Ix 1.1 and Ix 1.2 together contain most of the argillaceous limestone samples, with Ix 1.2 containing most of the calcareous mudstone samples. Ix 2.1-2.6 contain most of the siltstone and sandstone samples.

FIG. 14. Index Limestone. Plot of: (a) the first and second principal components, and (b) the second and third principal components in the PCA of the numbers of genera present in higher taxa showing the fields occupied by the two major clusters (Ix 1-2) identified in Figure 13. For sample details see Supplementary material.

FIG. 15. Hurlet Limestone. Ranges of lithofacies and environments of the taxa selected from the genus-level seriation using all samples constrained, for the unique taxa excluded data set. The dotted lines indicate interpolated presence.

FIG. 16. Index Limestone. Faunal gradients of taxa that have the most extensive range within the carbonate depositional environment and extend increasingly into the siliciclastic depositional environment. Based on a seriation of all the consolidated 
Ayrshire methods submitted for publication.doc

genus-level data, the samples being constrained to the order obtained by seriating the limestone samples alone. The dotted lines indicate interpolated presence.

FIG. 17. Index Limestone. Faunal gradients of taxa that have a limited range within the carbonate depositional environment and extend furthest into the coarse siliciclastic depositional environment. Based on the seriation of all the consolidated genus-level data, the samples being constrained to the order obtained by seriating the limestone samples alone. The dotted lines indicate interpolated presence. 


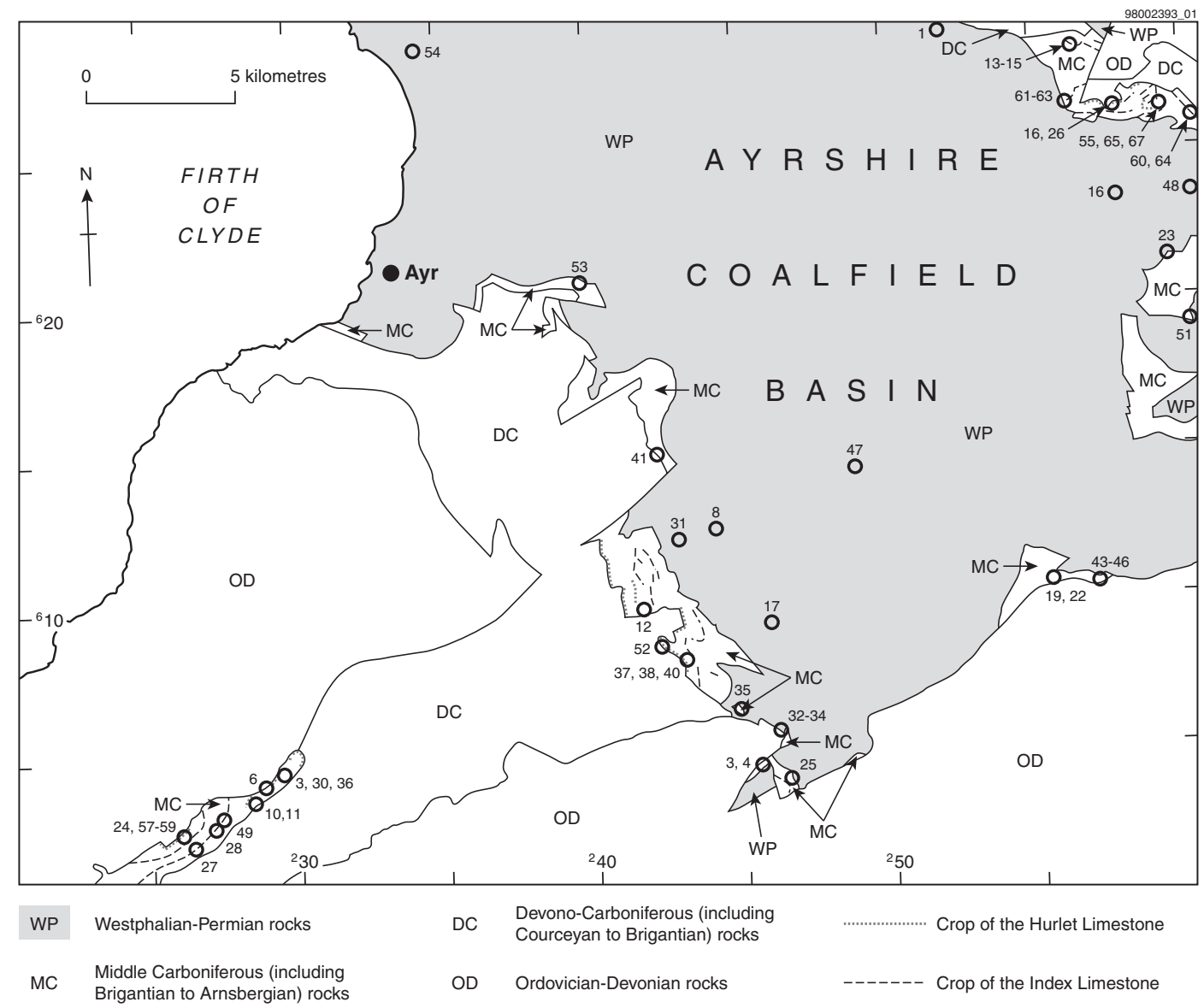

- Sampling locality 


\begin{tabular}{|c|c|c|c|c|c|c|c|c|}
\hline \multicolumn{3}{|c|}{ Standard Divisions } & \multirow{2}{*}{$\begin{array}{c}\text { Subsystem } \\
\text { (obsolete) }\end{array}$} & \multicolumn{3}{|c|}{ Regional Divisions } & \multicolumn{2}{|c|}{ Lithostratigraphical Units } \\
\hline $\begin{array}{l}\text { Sub- } \\
\text { system }\end{array}$ & Series & Stage & & \multicolumn{2}{|l|}{ Series } & \multirow{2}{*}{$\begin{array}{c}\text { Stage } \\
\text { Bolsovian }\end{array}$} & \multirow{2}{*}{$\begin{array}{c}\text { Formations } \\
\text { Scottish Upper Coal Measures }\end{array}$} & Groups \\
\hline \multirow{4}{*}{ 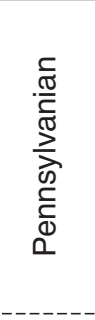 } & $\begin{array}{l}\text { Middle } \\
\text { (pars) }\end{array}$ & \begin{tabular}{|c|} 
Moscovian \\
(pars)
\end{tabular} & \multirow{6}{*}{ Silesian } & \multirow{3}{*}{ Westphalian } & C & & & \multirow{3}{*}{$\begin{array}{l}\text { Scottish Coal } \\
\text { Measures Group }\end{array}$} \\
\hline & \multirow{3}{*}{ 㐫 } & \multirow{3}{*}{ 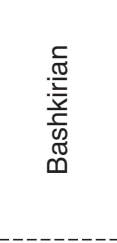 } & & & B & Duckmantian & Scottish Middle Coal Measures & \\
\hline & & & & & A & Langsettian & Scottish Lower Coal Measures & \\
\hline & & & & \multirow{3}{*}{\multicolumn{2}{|c|}{ Namurian }} & $\begin{array}{l}\text { Chokierian- } \\
\text { Yeadonian }\end{array}$ & Passage Formation & \multirow{4}{*}{$\begin{array}{l}\text { Clackmannan } \\
\text { Group } \\
\text { Index Limestone }\end{array}$} \\
\hline \multirow{9}{*}{$\begin{array}{l}\frac{c}{.0} \\
\frac{0}{0} \\
\frac{2}{D} \\
\frac{.0}{D} \\
\frac{.0}{2}\end{array}$} & \multirow{2}{*}{$\begin{array}{l}\frac{\grave{0}}{2} \\
\stackrel{\circ}{2}\end{array}$} & \multirow{2}{*}{ 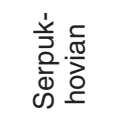 } & & & & Arnsbergian & Upper Limestone Formation & \\
\hline & & & & & & Pendleian & Limestone Coal Formation & \\
\hline & \multirow{4}{*}{$\frac{\stackrel{0}{0}}{\stackrel{0}{\frac{O}{2}}}$} & \multirow{4}{*}{ 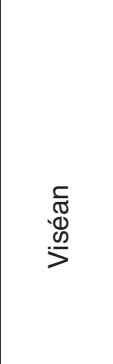 } & \multirow{7}{*}{ Dinantian } & \multirow{4}{*}{\multicolumn{2}{|c|}{ Viséan }} & \multirow{2}{*}{ Brigantian } & Lower Limestone Formation & \\
\hline & & & & & & & Lawmuir Formation & \multirow[b]{3}{*}{$\begin{array}{l}\text { Strathclyde } \\
\text { Group }\end{array}$} \\
\hline & & & & & & \multirow[b]{2}{*}{$\begin{array}{l}\text { Arundian- } \\
\text { Holkerian }\end{array}$} & Kirkwood Formation & \\
\hline & & & & & & & $\begin{array}{l}\text { Clyde Plateau } \\
\text { Volcanic Formation }\end{array}$ & \\
\hline & \multirow{3}{*}{ ฏें } & \multirow{3}{*}{ 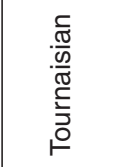 } & & \multirow{3}{*}{\multicolumn{2}{|c|}{ Tournaisian }} & Chadian & Clyde Sandstone Formation & \multirow{3}{*}{$\begin{array}{l}\text { Inverclyde } \\
\text { Group }\end{array}$} \\
\hline & & & & & & \multirow{2}{*}{ Courceyan } & Ballagan Formation & \\
\hline & & & & & & & Kinnesswood Formation & \\
\hline
\end{tabular}




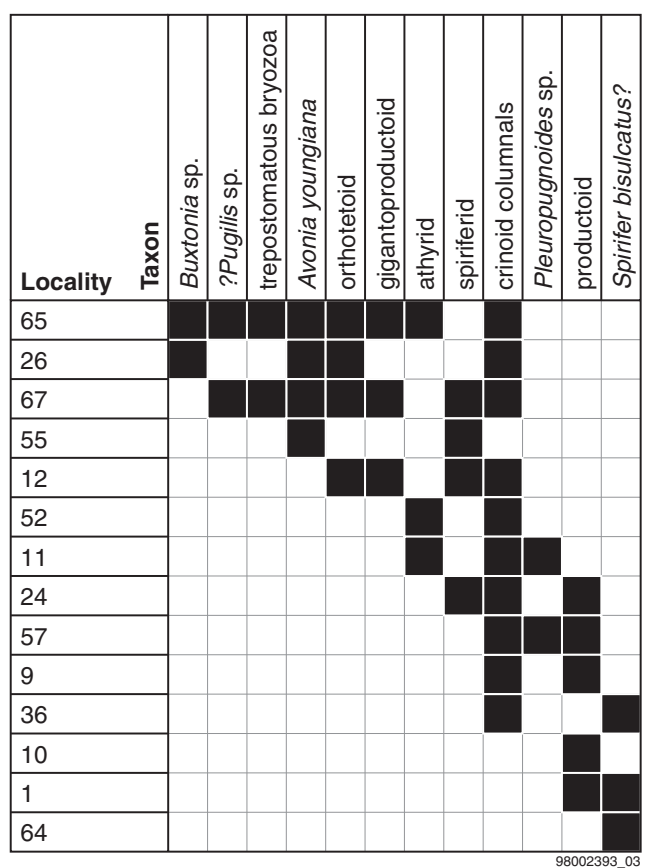


Dice

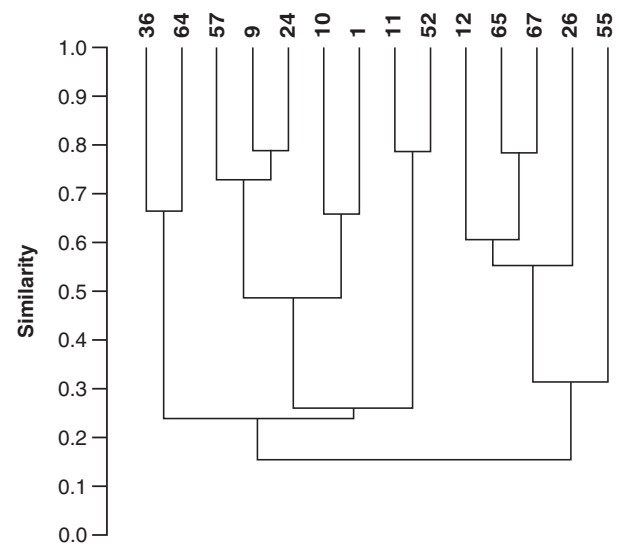

Raup-Crick

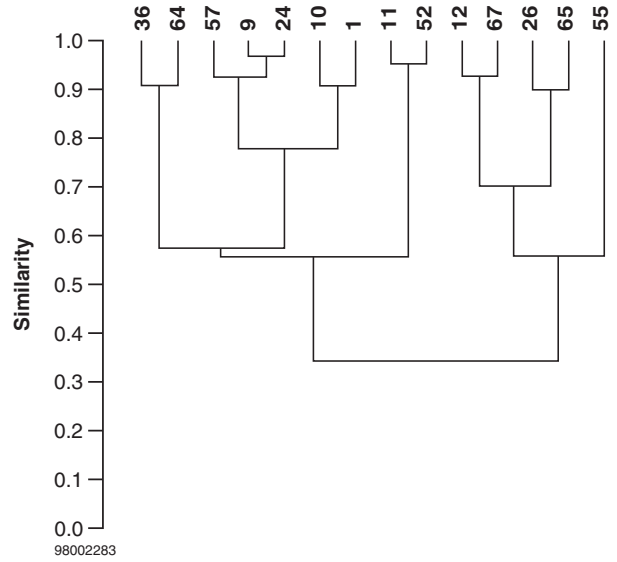

Simpson

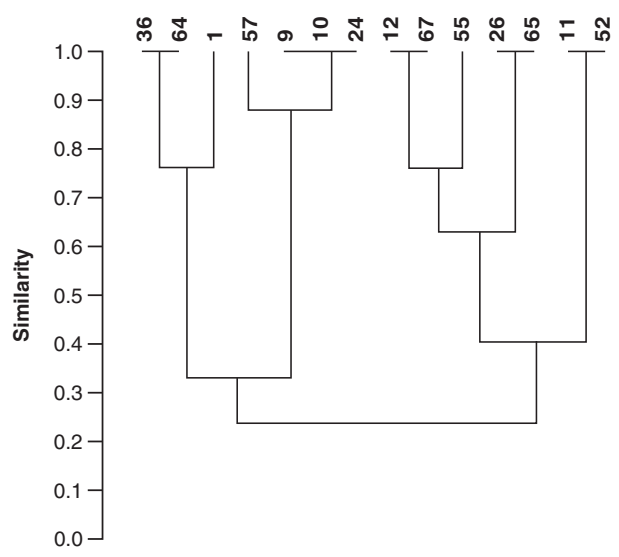

Localities

1 Auchmillanhill Bore

9 Cairnshalloch Limeworks

10 Captain's Bridge

11 Captain's Glen

12 Carskeoch

24 Dailly Station

26 Daldilling

36 Heronspark Burn

52 Meikleholm Burn

55 Nethershield

57 Quarrelhill Burn

64 River Ayr (Upper Heilar)

65 River Ayr (Windy Burn)

67 Windy Burn 


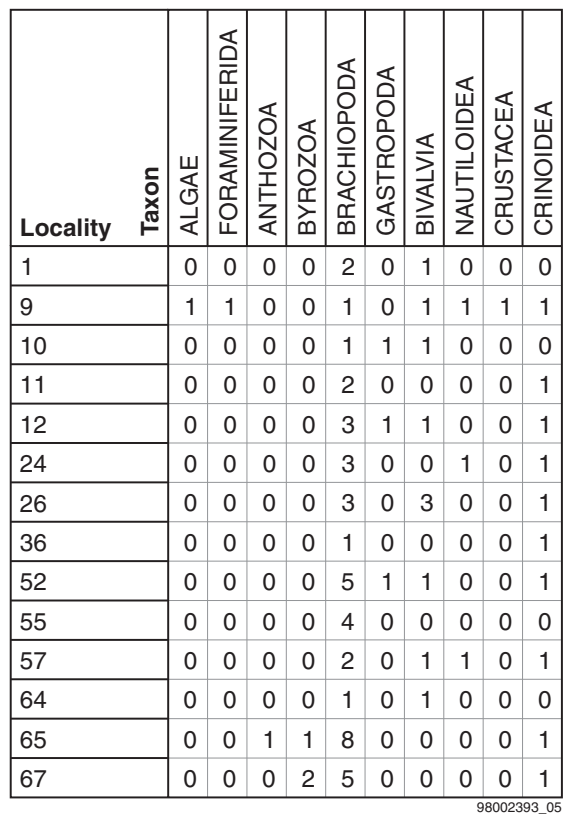




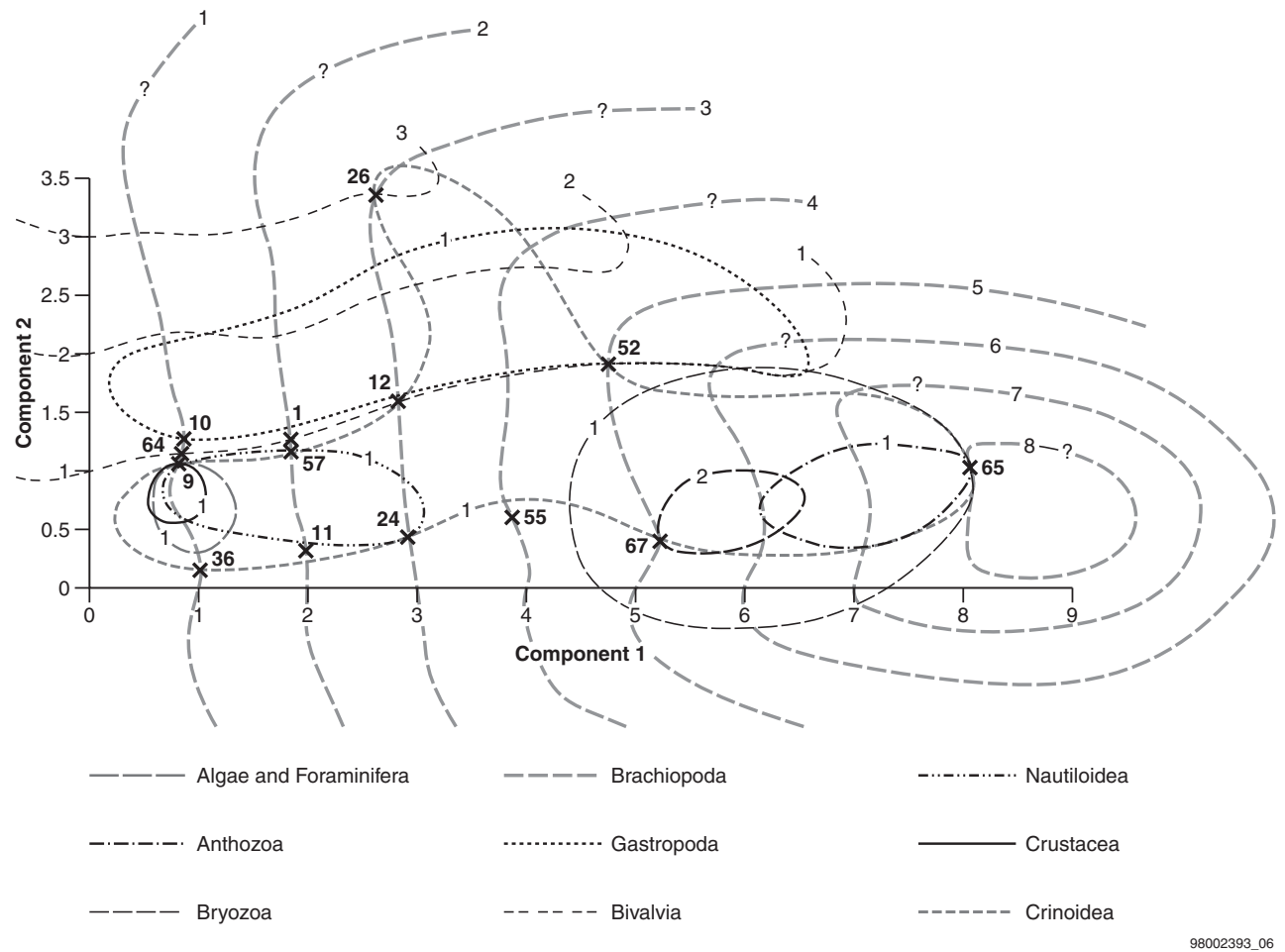




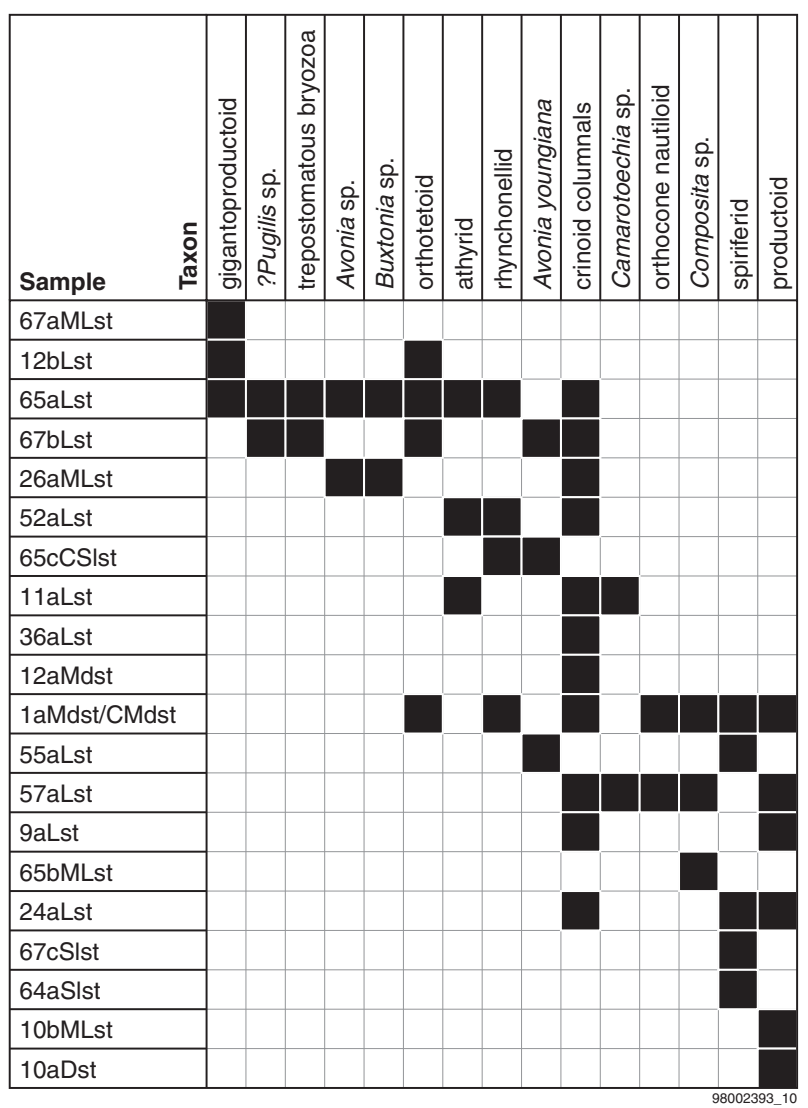




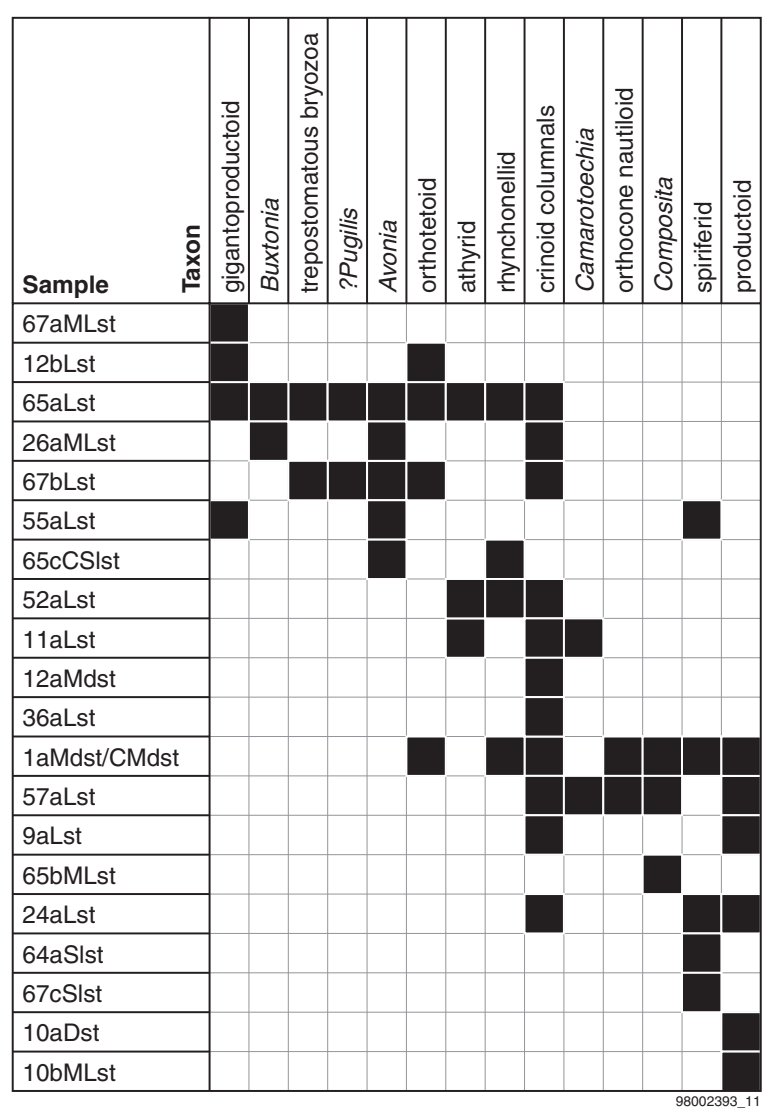




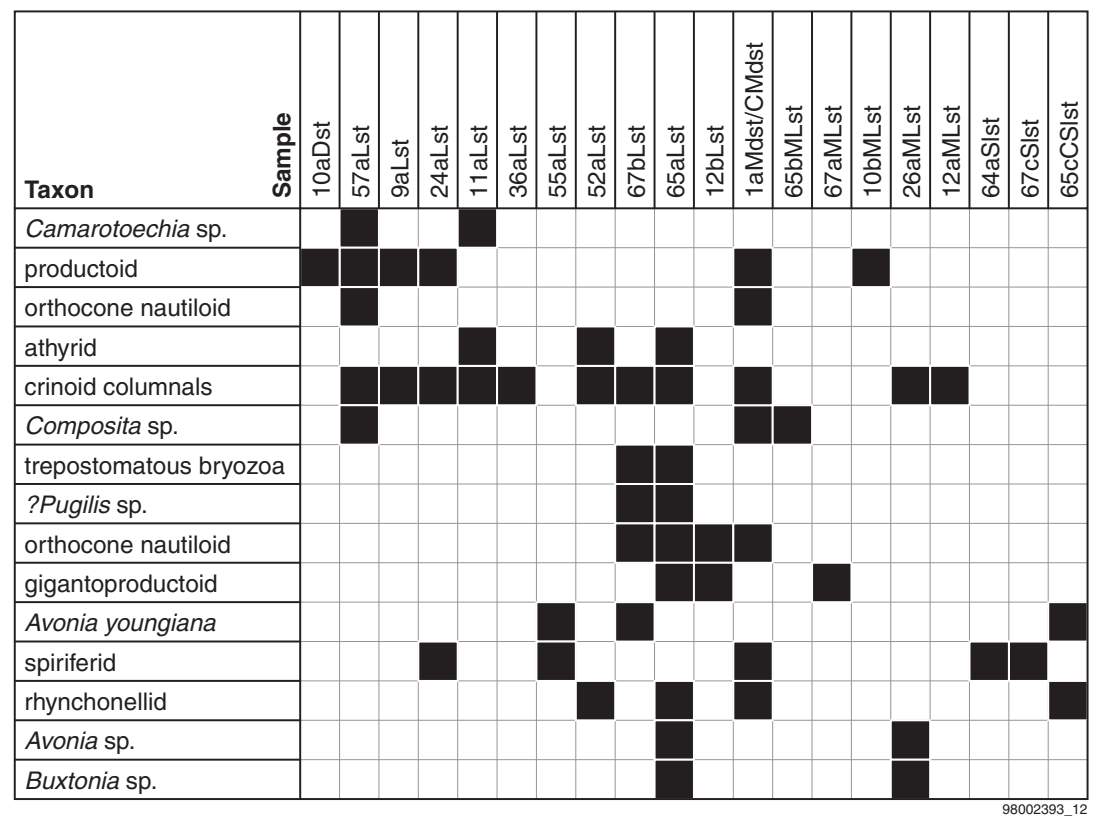




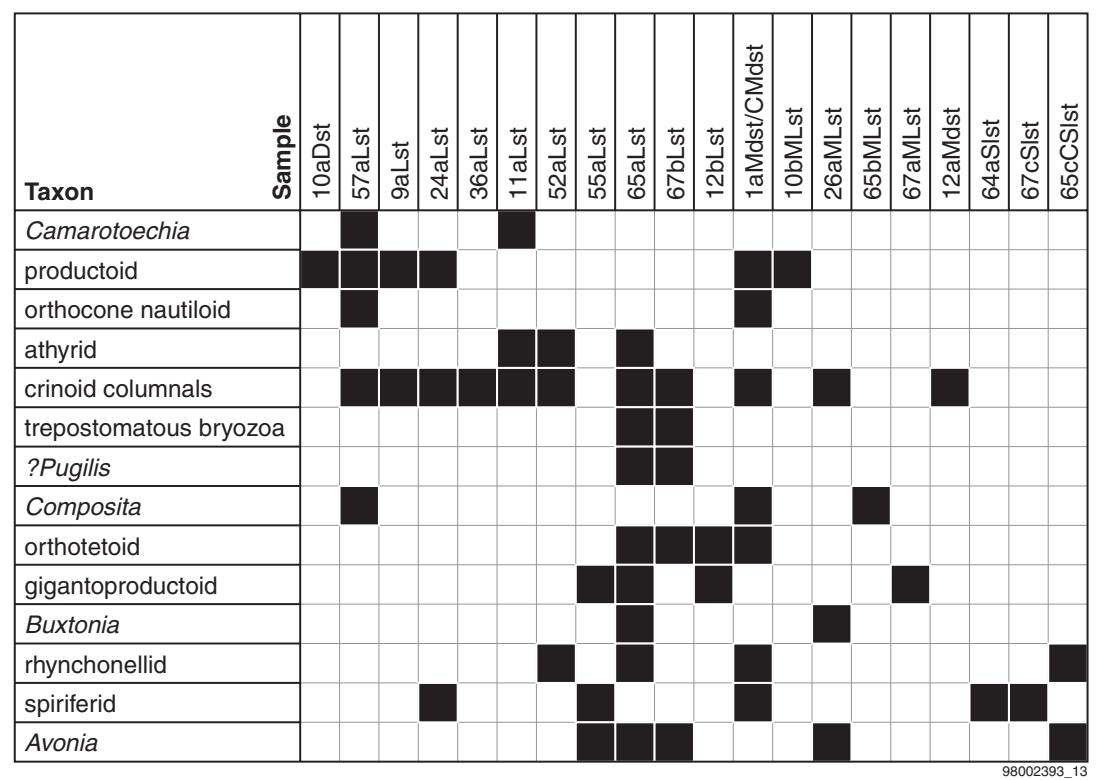




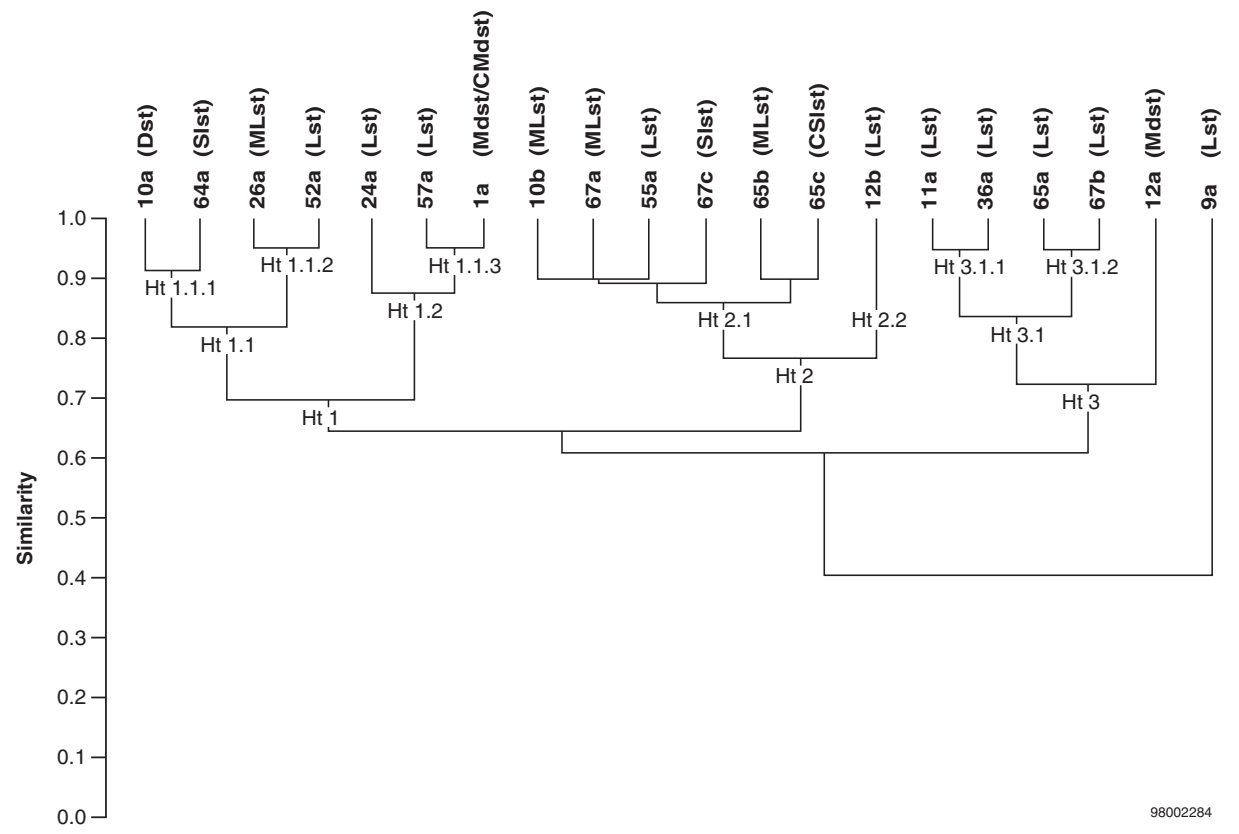


a)

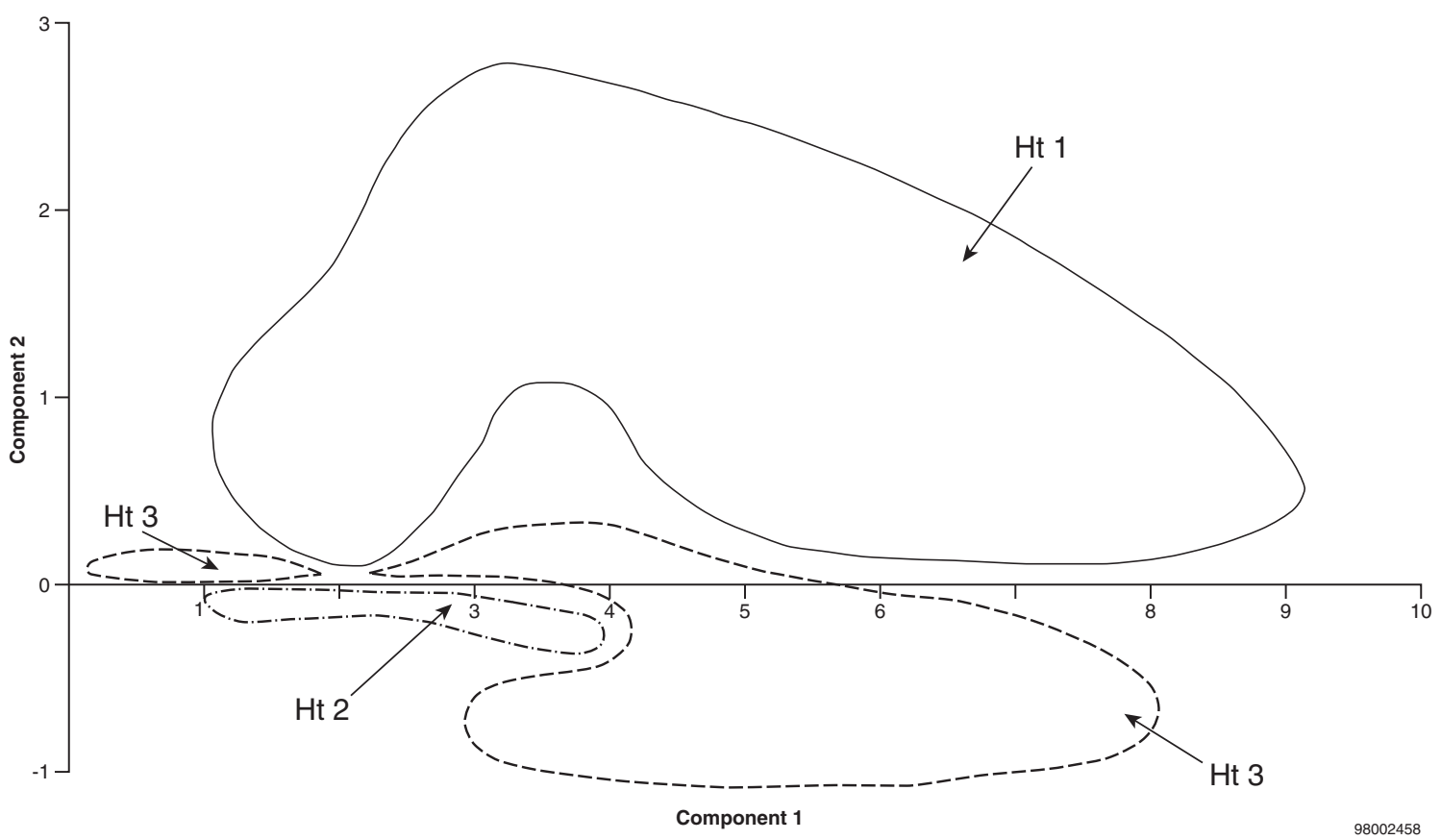

b)

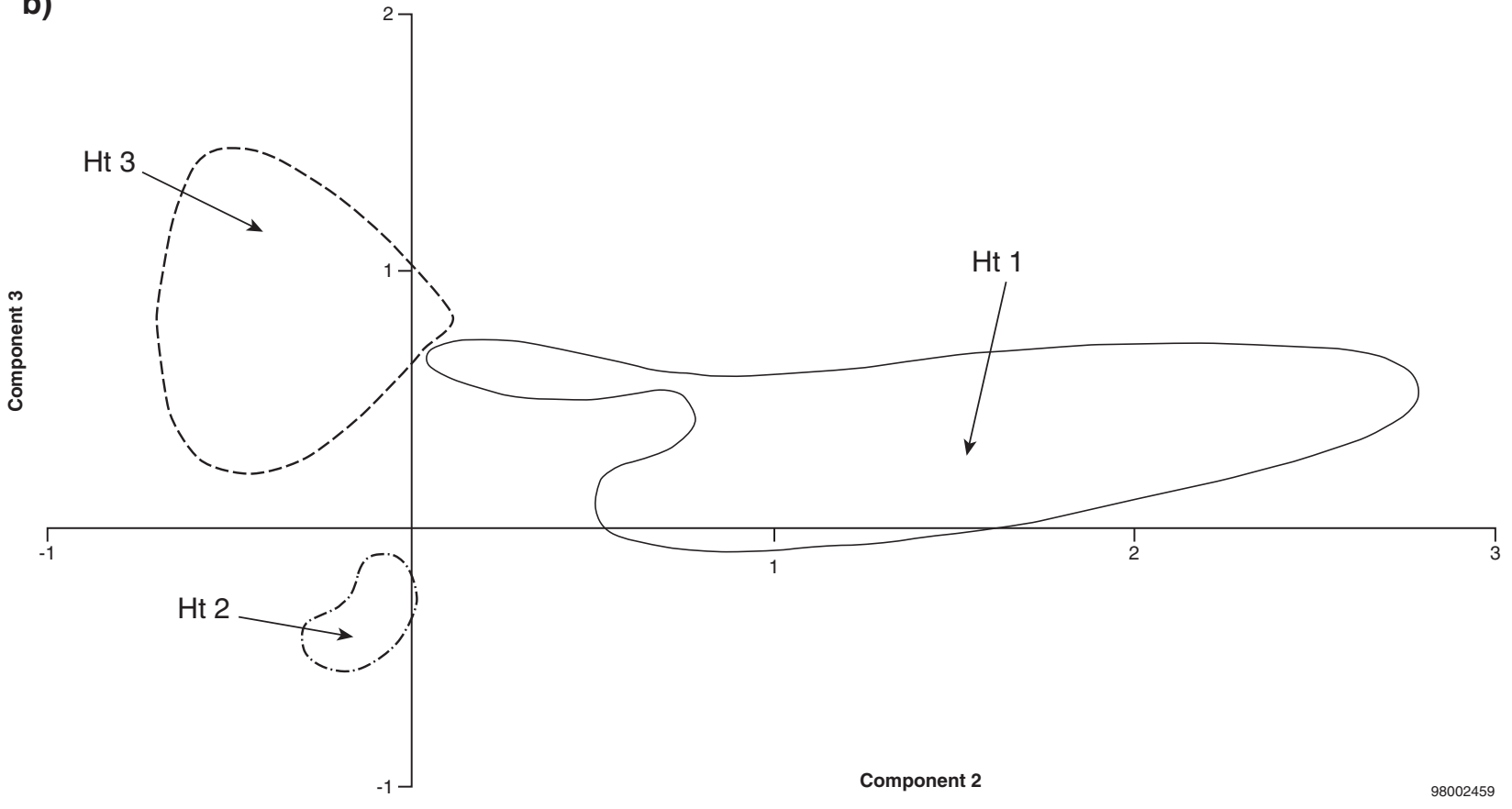




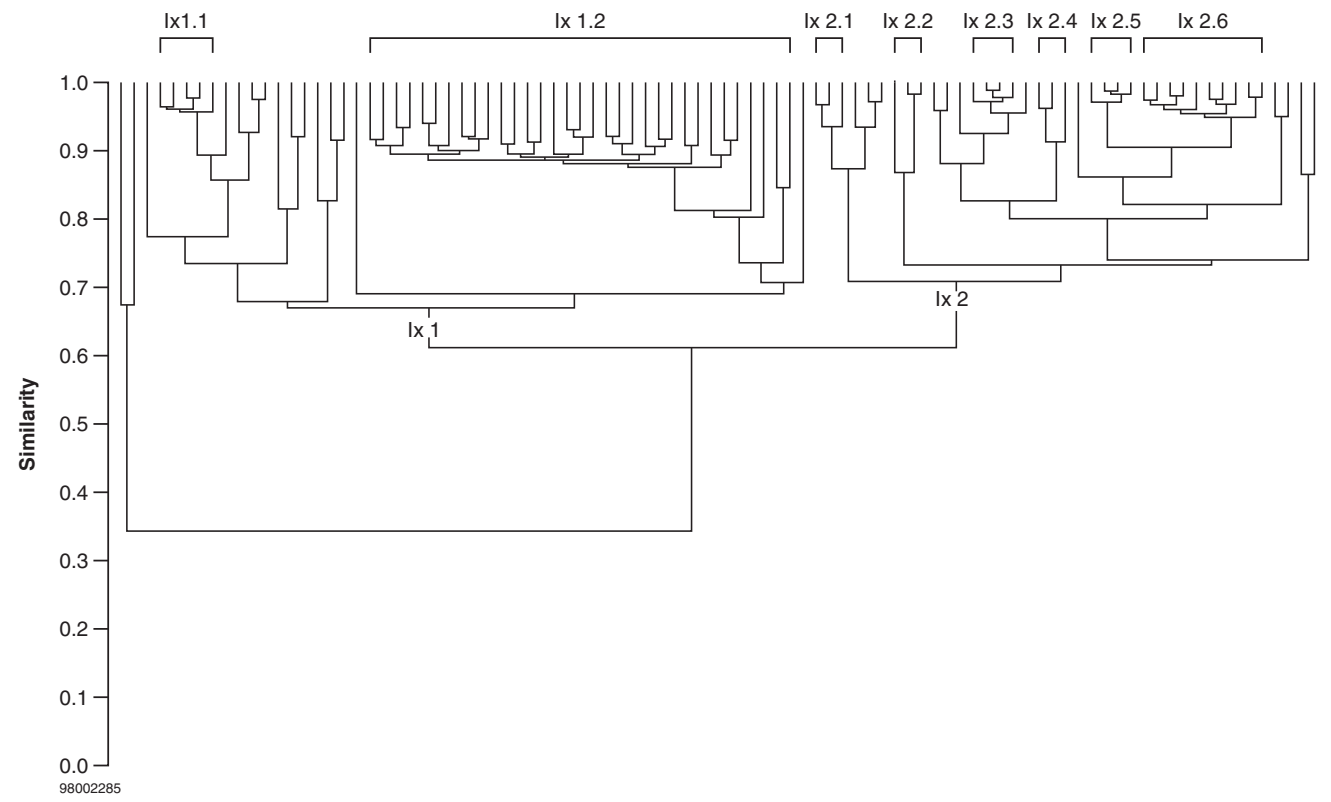




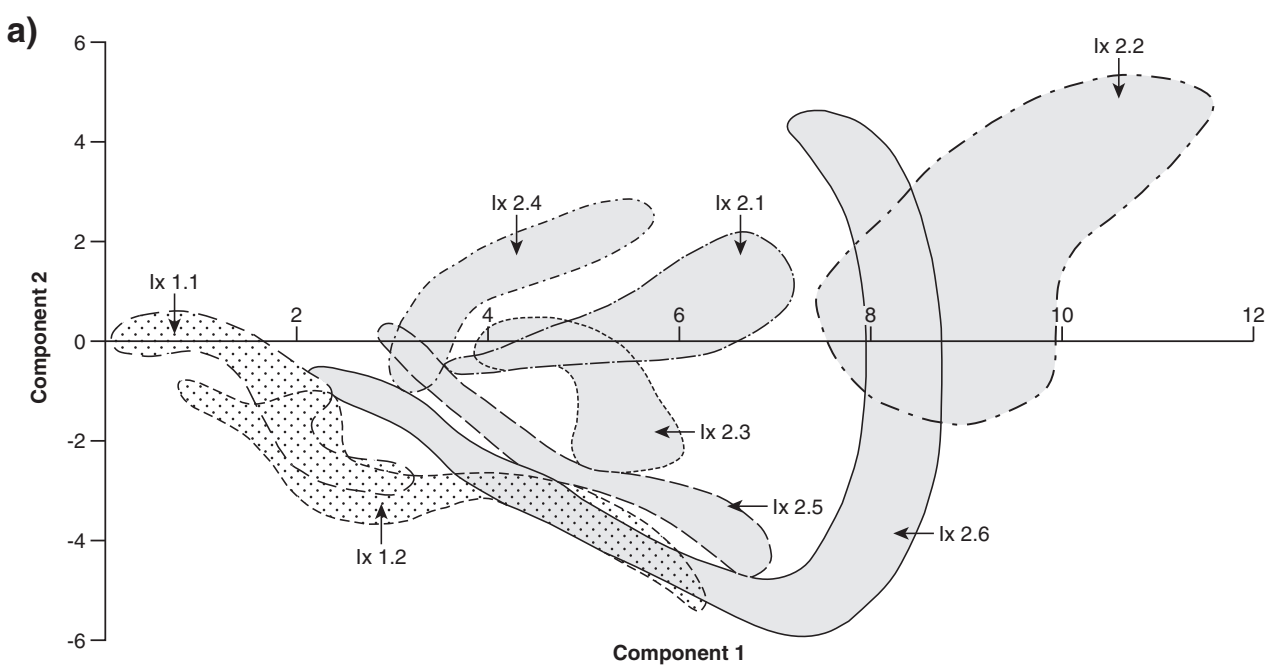

b)

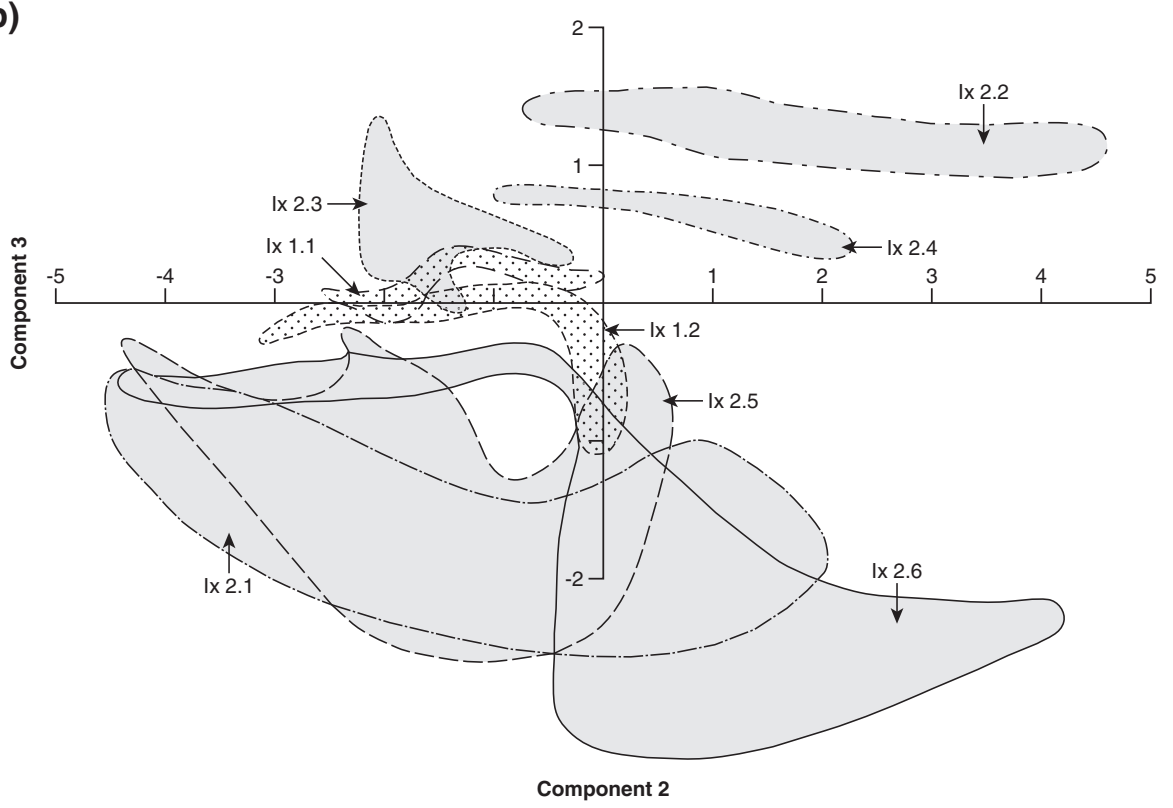

$\because \because \quad \because \quad$ Ix $\quad$ Ix 


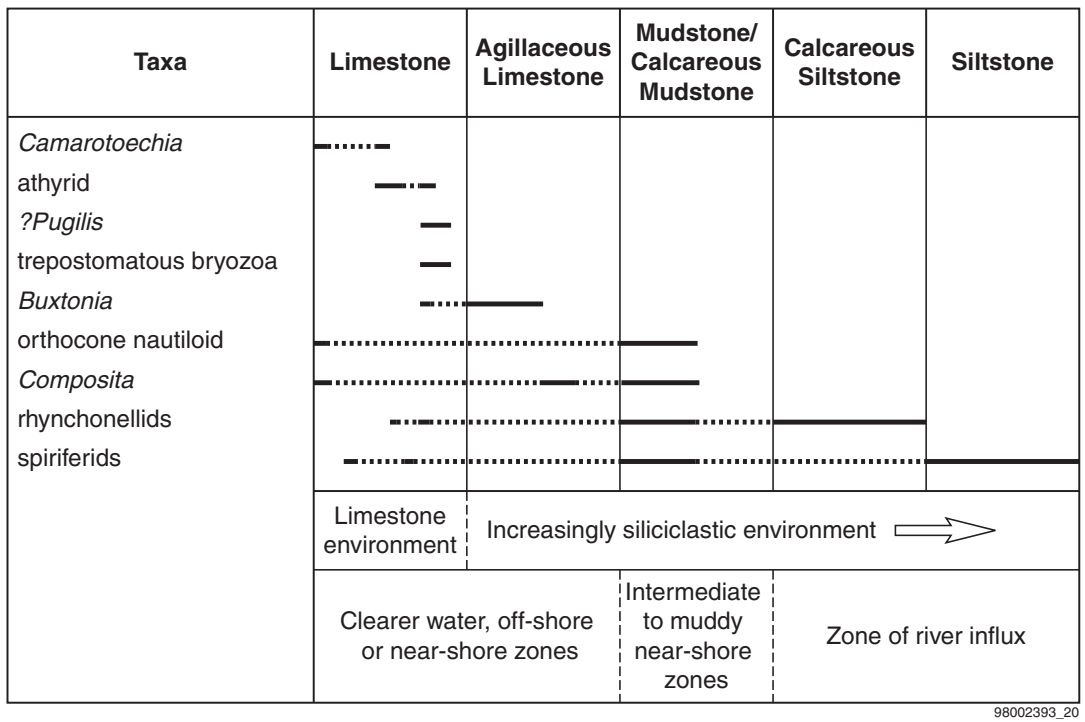




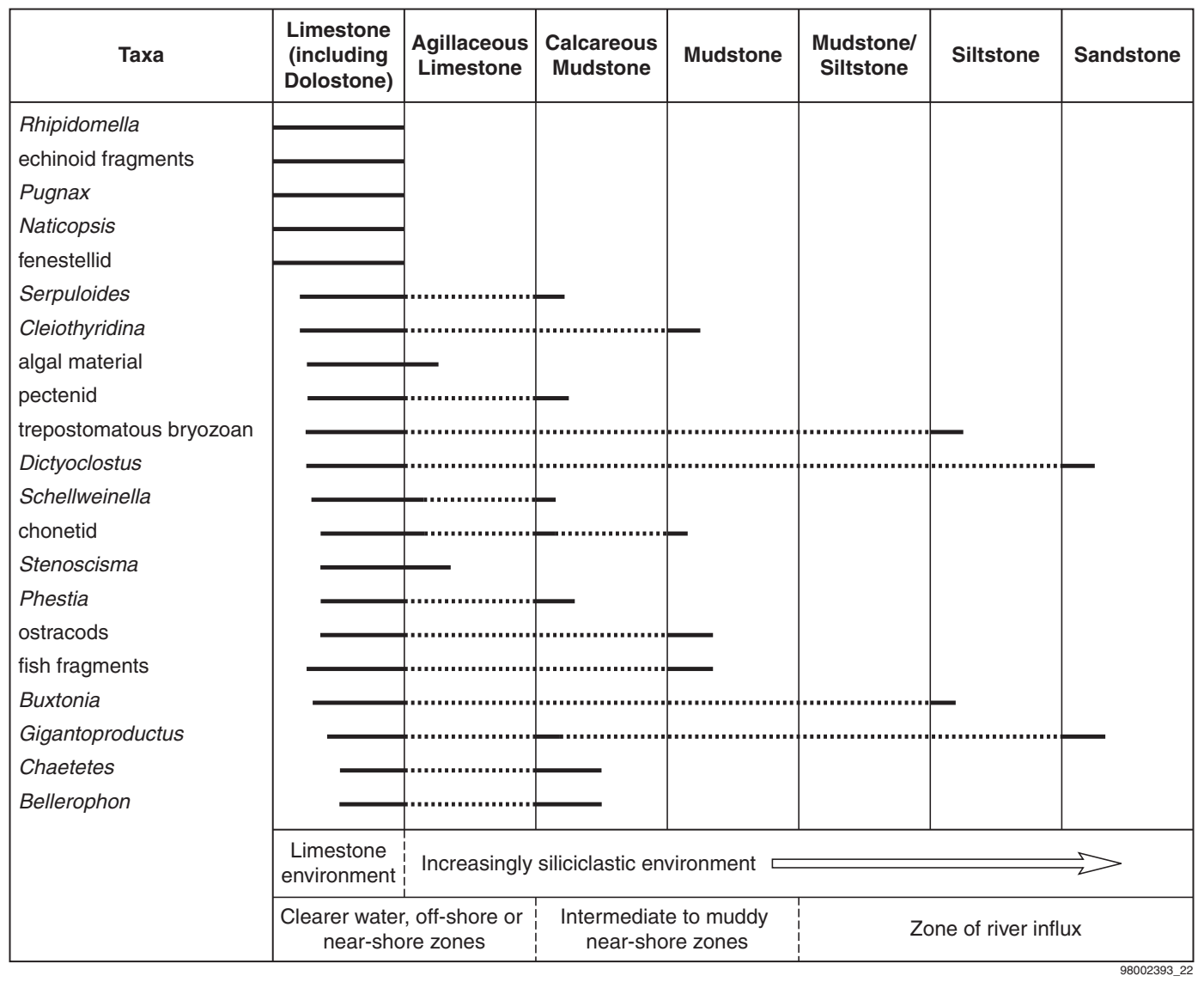




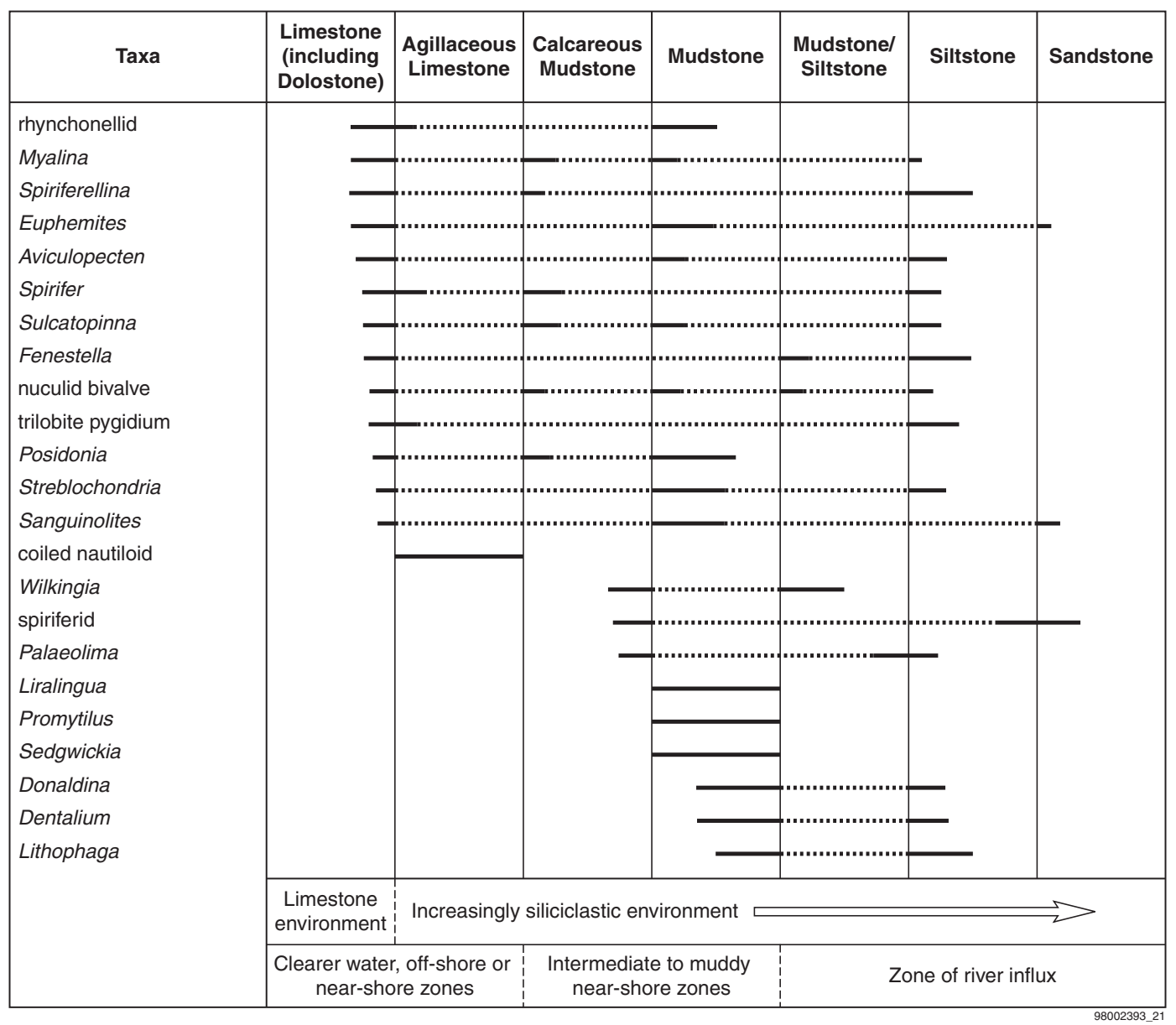


Localities, taxa and sample lithologies used on the diagrams

Localities Taxa

Number Name Limestone Grid Reference [NS] Taxon

$\begin{array}{lll}1 \mathrm{a} & \text { Auchmillan Hurlet } & {[51712894]} \\ 2 \mathrm{a} & \text { Auldcraigo Index } & {[4561 \text { 0421] }}\end{array}$

$3 a$

Auldcraigo Index [4515 0439]

Auldcraigo Index [4523 0441]

Auldcraigo Index [4523 0441]

Auldcraigo Index [4523 0441]

Auldcraigo Index [4511 0442]

Auldcraigoı Index [4511 0442]

Auldcraigo Index [4511 0442]

Auldcraigoı Index [4511 0442]

Baldrennar Index [2880 0407]

Blairmulloc Index [5605 2820]

Bowhill Bor Index [4381 1231]

Bowhill Bor Index [4381 1231]

Cairnshallc Hurlet [4080 1006]

Captains B Hurlet

Captains B Hurlet

Captains G Hurlet

[2851 0356]

[2851 0356]

[2851 0355]

Carskeoch Hurlet [4150 0966]

Carskeoch Hurlet [4150 0966]

Cleuch Bur Index [5604 2817]

Cleuch Bur Index [5613 2813]

Cleuch Bur Index [5605 2818]

Common B Index

[5734 2322]

Common BIndex

[5734 2322]

Common B Index

[5734 2322]

Common B Index

[5734 2322]

Corbie Cra Index

[4553 0920]

Corbie Cra Index

[4553 0920]

Corbie Cra Index

[4553 0920]

Craighouse Index

[5487 1046]

Craighouse Index

Craighouse Index

[5483 1038]

[5483 1038]

Craighous I Index

$20 \mathrm{a}$

$21 \mathrm{a}$

$22 \mathrm{a}$

$22 \mathrm{~b}$

Craighous I Index

Craighouse Index

Craighouse Index

Craighouse Index

Craigston + Index

[5482 1041]

[5489 1047]

[5486 1043]

[5486 1043]

[5486 1043]

[5908 2130]

Craigston I Index

[5908 2130]

Craigston $\mathrm{H}$ Index

Dailly Stati Hurlet

[5908 2130]

[2601 0246]

Dalcairnie I Index

$25 a$

$26 a$

Daldilling Hurlet

[4614 0387]

Dalquharra Index

[5738 2625]

[2653 0206]

Dalquharra Index

[2653 0206]

[2721 0274]

[2721 0274]

Dalquharra Index

[2721 0274]

[4310 0946]

Drumgrang Index

$29 a$

$30 \mathrm{a}$

Drummoch Index

[2955 0444]

Drummoch Index

[2955 0444]

$31 \mathrm{a}$

[4263 1200]

\section{PLANTAE}

Lepidophyllum sp.

Odontopteris sp.

Abbreviation

Hurlet Limestone Anal' Index Lime

Species Genus Species

ALGAE

algal mater alga alga alga

FORAMINIFERIDA

foraminifer fora fora

PORIFERA

'Chaetetes tumidus' $\mathrm{CHAt}$

ANTHOZOA

clisiophyllid clis

Dibunophyllum sp. DIBU

zaphrentid zaph

coral indete cora cora cora

BRYOZOA

Fenestella FENs Fene FENS

fenestellid fene

trepostome t-br t-br t-br

ANNELIDA

Serpuloides sp. SERP

?Serpuloides sp. ?SER

BRACHIOPODA

Actinoconchus sp. ACTs

Angiospiriff A1ct Angi A1ct

Antiquatonia muricata (Phillips) A2mu

Antiquaton $\mathrm{A} 2 \mathrm{~m}$ ? Anti A2m?

Antiquatonia cf. muricata (Phillips) A2cm

Antiquatonia sulcata (J Sowerby) ! A2sg

Antiquatonia sp. A2sp

?Antiquatonia sp. ?A2s

?Athyris sp. ?ATHs

athyrid Athd athy Athd

athyrid? Atd? athy Atd?

?Avonia davidsoni (Jarosz) ?Avd

Avonia you Avy Avon

Avonia sp. Avsp Avon

?Avonia sp?Avs Avon

?Beecheria sp. ?BEEs

Brachythyr BRAC Brac

Buxtonia scabricula (Martin) B1sc

Buxtonia scabricula (Martin)? B1s?

Buxtonia aff. scabricula (Martin) B1as

Buxtonia s|B1sp Buxt B1sp

?Buxtonia sp. ?B1s

Camarotoe CAMA Cama CAMA

chonetid chon chon chon

Cleiothyridina deroissyi (Léveillé) C1de

Cleiothyridina deroissyi (Léveillé)? C1d?

Cleiothyridina cf. fimbriata (Phillip؛ C1cf

Cleiothyridina glabistria (Phillips) C1gl

Cleiothyridina sp.

C1sp 


\begin{tabular}{|c|c|c|}
\hline $31 b$ & Drysdales | Index & [4263 1200] \\
\hline $31 c$ & Drysdales I Index & [4263 1200] \\
\hline $32 a$ & Glenhead IIndex & {$\left[\begin{array}{llll}4590 & 0560\end{array}\right]$} \\
\hline $32 b$ & Glenhead I Index & [4590 0560] \\
\hline $32 \mathrm{c}$ & Glenhead IIndex & [4590 0560] \\
\hline $33 a$ & Glenhead IIndex & [4590 0561] \\
\hline $33 b$ & Glenhead I Index & [4590 0561] \\
\hline $34 a$ & Glenhead IIndex & [4590 0562] \\
\hline $34 b$ & Glenhead I Index & [4590 0562] \\
\hline $35 a$ & Grimmet Fi Index & [4463 0627] \\
\hline $36 a$ & Heronsparl Hurlet & [2939 0456] \\
\hline $37 a$ & Keirs Burn Index & [4298 0802] \\
\hline $37 \mathrm{~b}$ & Keirs Burn Index & [4298 0802] \\
\hline $38 a$ & Keirs Burn Index & [4309 0809] \\
\hline $8 b$ & Keirs Burn Index & [4309 0809] \\
\hline $39 a$ & Keirs Burn Index & [4279 0803] \\
\hline $40 a$ & Keirs Glen Index & [4310 0805] \\
\hline $41 a$ & Kerse Park Index & [4218 1485] \\
\hline $41 b$ & Kerse Park Index & [4310 0805] \\
\hline $42 a$ & Knockburn Index & [5634 1032] \\
\hline $42 b$ & Knockburn Index & [5634 1032] \\
\hline $43 a$ & Knockburn Index & [5634 1029] \\
\hline $43 b$ & Knockburn Index & [5634 1029] \\
\hline $44 a$ & Knockburn Index & [5634 1028] \\
\hline $45 a$ & Knockburn Index & [5634 1027] \\
\hline $46 a$ & Knockburn Index & [5634 1024] \\
\hline $46 b$ & Knockburn Index & [5634 1024] \\
\hline $47 a$ & Knockguldı Index & [4833 1425] \\
\hline $47 \mathrm{~b}$ & Knockguldı Index & [4833 1425] \\
\hline $48 a$ & Lands of M Index & [5984 2337] \\
\hline $48 b$ & Lands of M Index & [5984 2337] \\
\hline $49 a$ & Maxwell C(Index & [2746 0298] \\
\hline $50 a$ & Maxwell Rá Index & [2742 0296] \\
\hline $51 a$ & Meikle Auc Index & [5982 1899] \\
\hline $51 b$ & Meikle Auc Index & [5982 1899] \\
\hline $51 \mathrm{c}$ & Meikle Auc Index & [5982 1899] \\
\hline $52 a$ & Meikleholr Hurlet & [4205 0848] \\
\hline $53 a$ & Millcraig Index & [3959 2081] \\
\hline $54 a$ & Monktonhil Index & [3457 2849] \\
\hline $54 b$ & Monktonhil Index & [3457 2849] \\
\hline $55 a$ & Nethershie Hurlet & [5881 2626] \\
\hline $56 a$ & Polquhairn Index & [4733 1499] \\
\hline $57 a$ & Quarrelhill Hurlet & [2602 0246] \\
\hline $58 a$ & Quarrelhill Index & [2601 0246] \\
\hline $59 a$ & Quarrelhill Index & [2630 0250] \\
\hline $60 a$ & River Ayr Index & [5977 2585] \\
\hline $61 a$ & River Ayr Index & [5593 2626] \\
\hline $61 b$ & River Ayr Index & [5593 2626] \\
\hline $61 c$ & River Ayr Index & [5593 2626] \\
\hline $61 d$ & River Ayr Index & [5593 2626] \\
\hline $62 a$ & River Ayr Index & [5588 2629] \\
\hline $62 b$ & River Ayr Index & [5588 2629] \\
\hline $63 a$ & River Ayr (! Index & [5568 2636] \\
\hline $64 a$ & River Ayr (' Hurlet & [5997 2599] \\
\hline $65 a$ & River Ayr ('Hurlet & [5886 2627] \\
\hline $65 b$ & River Ayr (' Hurlet & {$\left[\begin{array}{lll}5886 & 262\end{array}\right]$} \\
\hline
\end{tabular}

?Cleiothyridina sp. ?C1s

Composita ambigua (J Sowerby) c2am

Composita ambigua (J Sowerby)? C2a?

Composita cf. ambigua (J Sowerb C2ca

?Composita ambigua (J Sowerby ?C2a

Composita C2sp Comp C2sp

?Composit ?C2s Comp ?C2s

Crurithyris urii (Fleming) CRUi

Dictyoclostus semireticulatus (MaI DICs

Dielasma sp. DIEs

Echinoconchus sp. ECHs

?Echinoconchus sp. ?ECH

Eomarginif Ello Eoma Ello

Eomarginifera cf. longispina (J So E1cl

?Eomarginifera cf. longispina (J S ?E1l

Eomarginifera praecursor (Muir-W E1pr

Eomarginifera praecursor (Muir-W E1p?

Eomarginifera cf. praecursor (Muil E1cp

Eomarginifera sp. E1sp

'Fusella convoluta' FUSc

Gigantopro GIGg Giga GIGg

Gigantopro GIGs Giga GIGs

gigantoprorgiga Giga giga

Krotovia aculeata (J Sowerby) KROa

Latiproductus latissimus (J Sowerl L1la

Latiproductus latissimus (J Sower L1l?

Latiproducl L1cl Lati L1Cl

Latiproductus sp. L1sp

?Latiproductus sp. ?L1s

Lingula mytilloides J Sowerby L2my

Lingula squamiformis Phillips L2sq

Lingula cf. squamiformis Phillips L2cs

Lingula sp. L2sp Ling L2sp

Liralingua indicis Graham LIRi

Martinia sp. MART

?Martinia sp. ?MAR

Orbiculoidea cincta (Portlock) ORBc

Orbicoloidea cincta (Portlock)? ?ORB

Orbiculoidea cf. nitida (Phillips) ORBn

orthid orth

orthotetoid orto orth orto

orthotetoid? ort?

Phricodothyris lineata (J Sowerby', P1li

Phricodothyris lineata (J Sowerby', P1l?

Phricodothyris cf. lineata (J Sower P1cl

Phricodothyris sp. P1sp

?Phricodothyris sp. ?P1s

Pleuropugnoides pleurodon (Philli PLEp

Pleuropugr $G \quad$ PLEs

Productus cf. carbonarius de Koni P2ca

Productus concinnus J Sowerby P2co

Productus cf. concinnus J Sowerb P2co

Productus P2sp Prod P2sp

?Productus sp. ?P2s

productoid prod Prod prod

Pugilis cf. pugilis (Phillips) PUGp 
River Ayr ('Hurlet Watston Bı Index Windy Burr Hurlet Windy Burr Hurlet Windy Burr Hurlet
Pugilis sp. PUGs

?Pugilis sp ?PUG Pugi

Pugnax cf. pugnus (Martin) P3cp

?Pugnax sp.

?P3s

?Punctospi?PUN Punc ?PUN

Pustula cf. pustulosa (Phillips) PUSP

Pustula sp. PUSs

Rhipidomella michelini Léveillé? RHm?

?Rhipidomella michelini Léveillé ?RHm

rhynchonel rhyn rhyn rhyn

Rugosochonetes hardrensis (Phill RUGh

Rugosochc RUGs Rugo

Rugosochonetes sp. Rusp

Schellweinella crenistria (Phillips) SCHc

Schellweinella sp. $\quad \mathrm{SCHs}$

?Schellweinella sp. ?SCH

Schizophoria resupinata (Martin) S1re

Schizophoria cf. resupinata (Marti S1cr

Schizophoria sp.

S1sp

?Schizophoria sp.

?S1s

Spirifer bisı SPb? SPI1

Spirifer bisulcatus J de C Sowerb) SPbg

?Spirifer sp.

?SPS

Spiriferellina octoplicata (J de C S S2oc

Spiriferellina cf. perplicata (North) S2cp

Spiriferellina sp.

S2sp

spiriferid spir spir

Stenoscisn STEs Sten STEs

?Stenoscisma sp. ?STE

brachiopod brac brac brac

GASTROPODA

Bellerophon sp. BELs

?Bellerophon sp. ?BEL

bellerophontid bell

Donaldina sp. DONs

Euphemites ardenensis (Weir)? EUa?

Euphemites cf. hindi (Weir) EUch

Euphemites urii (Fleming) EUur

Euphemites sp. EUsp

Glabrocingulum sp. $\quad$ GLAB

'Loxonema curvilineum' LOXC

loxonematiid loxo

Meekella sp. MEEK

Naticopsis variata (Phillips) NATV

?Naticopsi: ?NAT Nati

pleurotomariid? pleu

Porcellia sp. PORC

Retispira decussata (Fleming)? REd?

Retispira cf. decussata (Fleming) REcd

Retispira striata (Fleming)? REst

Retispira sp. REsp

Soleniscus sp. SOLE

Straparollus carbonarius (J de C $\leqslant$ STRC

pupaeform gastropod pupa

gastropod igast pupa gast

SCAPHOPODA 
Actinopteria persulcata (McCoy) A3pe

Anthraconeilo laevirostrum (Portlo A4la

?Anthraconeilo pentonensis (Hind ?A4p

?Anthraconeilo sp.

?A4S

Aviculopec AVIs

?Aviculopecten sp.

Avic

AVIS

Aviculopinr AVIm

Avpl

Cardiomor|cARe Card

?AVI

Edmondia maccoyi Hind?

CARe

Edmondia sulcata (Fleming)

Edm?

?Edmondia sulcata (Fleming)

Edsu

Edmondia sulcata (Fleming)?

?EDS

Edmondia sp.

EDS?

?Edmondic ?Eds

Edmo

EDsp

Euchondria sp.

?EDs

?Euchondria sp.

EUCS

Leiopteria sp.

?EUC

?Leiopteria sp.

?Limipecte ?LIM

?LEI

Lithophaga lingualis (Phillips)

LIli

Lithophaga lingualis (Phillips)?

LII?

Myalina verneuili (McCoy)?

MYV?

Myalina cf. verneuili (McCoy) MYcv

Myalina sp.

MYsp

Nuculopsis gibbosa (Fleming)

NUCg

nuculid?

nucu

Palaeolima cf. simplex (Phillips) PAcs

Palaeolima sp.

PAsp

?Palaeolima sp.

?PSa

Parallelodon semicostatus (McCo' PARs

pectenid

pect

Phestia attenuata (Fleming) PHEa

Posidonia corrugata (Etheridge ju POCo

Posidonia corrugata (Etheridge juı POc?

?Posidonia corrugata (Etheridge jı ?POc

?Posidonia sp. ?POs

?Promytilus sp. ?PRs

Prothyris sp. PROs

Saguinolites cf. clavatus Etheridg $\mathrm{SAcc}$ Sanguinolites plicatus (Portlock) SApl

Sanguinolites cf. plicatus (Portlock SAcp

Sanguinolites striatolamellosus de SAst

Sanguinolites variabilis McCoy grc SAvg

Sanguinolit SAsp Sang SAsp

?Sanguinolites sp. ?SAs

Schizodus sp. SCsp

?Schizodus sp. ?SCs

?Sedgwickia sp. ?SED

Solemya primaeva Phillips? SOLp

Solemya sp. SOLs

Streblochondria sp. STRE

Streblopteria ornata (Etheridge jur STor

?Streblopteria sp. ?STs 


\begin{tabular}{|c|c|c|}
\hline Sulcatopinı SUfl & Sulc & SUfl \\
\hline Sulcatopinna flabel & rmis (Marti & r SUf? \\
\hline Sulcatopinna sp. & & SUsp \\
\hline Wilkingia elliptica ( & llips) & WILe \\
\hline ?Wilkingia ?WIL & Wilk & ?WIL \\
\hline bivalve frac biva & biva & biva \\
\hline NAUTILOIDEA & & \\
\hline $\begin{array}{l}\text { Orthoceras sp. } \\
\text { 'cf. Soleno cSOL }\end{array}$ & SOLN & ORTH \\
\hline orthocone । nauo & naut & nauo \\
\hline coiled nautiloid & & nauc \\
\hline nautiloid indetermin & & naui \\
\hline AMMONOIDEA & & \\
\hline goniatite indetermir & & goni \\
\hline $\begin{array}{l}\text { ?goniatite indeterm } \\
\text { ARTHROPODA }\end{array}$ & & goni \\
\hline Paladin mucronatus & McCoy) & PALA \\
\hline trilobite pygidium & & \\
\hline trilobite fragments & eterminate & tril \\
\hline $\begin{array}{l}\text { CRUSTACEA } \\
\text { crustacean }\end{array}$ & & crus \\
\hline ostracods ostr & ostr & ostr \\
\hline $\begin{array}{l}\text { echinoid fragment } \\
\text { CRINOIDEA }\end{array}$ & & echi \\
\hline $\begin{array}{l}\text { Poteriocrinus sp. } \\
\text { crinoid colı crin } \\
\text { PISCES }\end{array}$ & crin & $\begin{array}{l}\text { POTc } \\
\text { crin }\end{array}$ \\
\hline $\begin{array}{l}\text { Petalodus psittacin } \\
\text { fish fragments }\end{array}$ & (McCoy)? & $\begin{array}{l}\text { PETA } \\
\text { fish }\end{array}$ \\
\hline $\begin{array}{l}\text { WACE FUSSILS burrows } \\
\text { worm }\end{array}$ & & orm \\
\hline
\end{tabular}




\begin{tabular}{lll} 
& \multicolumn{2}{l}{ Lithologies } \\
Abbreviatic Lithology \\
stone Analyses & CMdst & Calcareous mudstone \\
Genus & CSIst & Calcareous siltstone \\
& Dst & Dolostone \\
Lepi & Lst & Limestone \\
Odon & Mdst & Mudstone/Claystone (undifferentiated) \\
& MLst & Argillaceous limestone \\
alga & Slst & Siltstone \\
& Sst & Sandstone
\end{tabular}

Chae

clis

Figure 13

Dibu

Major Clus Nested Clu Sample Number

zaph

cora

Fene

fene

t-br

Serp

Serp

Ix 1

29a Lst

Ix 1

IX 1

41a Mdst

IX 1

IX 1

6a Lst

Ix 1.1

$15 \mathrm{a}$ Lst

IX 1

Ix 1.1 48a Mdst

Ix 1

Ix 1.1

49a MLst

Ix 1.1

54b Lst

Ix 1

Ix 1.1

28c Mdst

Ix 1

66a Dst

Acti

Ix 1

16c Lst

Angi

IX 1

16d MLst

Anti

Ix 1

42a Lst

Anti

IX 1

19a Lst

Anti

IX 1

IX 1

Anti

20a Slst

50a MLst/Lst

IX 1

Anti

Ix 1

Athy

athy

athy

Avon

Beec

Ix 1

Ix 1

Ix 1

Ix 1

IX 1

IX 1

7a Lst

23a Mdst

62b Lst

$17 \mathrm{a}$ Lst

Ix $1.2 \quad 5 b$ CMdst

Ix $1.2 \quad 5 \mathrm{c}$ MLst

Ix 1.2 47a Mdst

Ix 1

Ix 1.2

48b Lst

Ix 1.2

22b CMdst

IX 1

Ix 1.2

61b CMdst

IX 1

Ix 1.2

46b CMdst

Buxt

Ix 1.2

44a Lst/MLst

Buxt

Ix 1.2

63a Lst

Ix 1

Ix 1.2

46a Lst

Buxt

Ix 1.2

33a MLst

IX 1

Ix 1.2

62a Mdst

Cama

Ix 1.2

34b Lst

IX 1

Ix 1.2

43a Lst

IX 1

Ix 1.2

Ix 1.2

4c CMdst

Clei

Ix 1

Ix 1.2

4a Lst

Clei

IX 1

Ix 1.2

17b CMdst

Clei

Ix 1

Ix $1 \quad$ Ix $1.2 \quad$ 23b MLst

17c Mdst 


\begin{tabular}{|c|c|c|c|}
\hline Clei & Ix 1 & Ix 1.2 & 61c MLst \\
\hline Comp & Ix 1 & IX 1.2 & 54a Mdst \\
\hline Comp & Ix 1 & Ix 1.2 & $25 a$ Lst \\
\hline Comp & Ix 1 & IX 1.2 & $28 a$ Lst \\
\hline Comp & Ix 1 & Ix 1.2 & 34a CMdst \\
\hline Comp & Ix 1 & IX 1.2 & 22c Lst \\
\hline Comp & Ix 1 & IX 1.2 & 23c CMdst \\
\hline Crur & Ix 1 & Ix 1.2 & 37b MLst \\
\hline Dict & Ix 1 & Ix 1.2 & 61d SIst \\
\hline Diel & Ix 1 & Ix 1.2 & 45a CMdst \\
\hline Echi & Ix 1 & IX 1.2 & 22a Mdst \\
\hline Echi & Ix 1 & Ix 1.2 & 13a Mdst/CMdst \\
\hline Eoma & Ix 1 & IX 1.2 & 14a CMdst \\
\hline Eoma & Ix 1 & Ix 1.2 & 30a MLst \\
\hline Eoma & Ix 1 & & 5a Slst \\
\hline Eoma & $1 \times 2$ & Ix 2.1 & $5 d$ Mdst/Slst \\
\hline Eoma & $1 \times 2$ & IX 2.1 & 35a Lst \\
\hline Eoma & $1 \times 2$ & IX 2.1 & 51c Slst \\
\hline Eoma & $1 \times 2$ & & 31c Lst \\
\hline Fuse & $1 \times 2$ & & 38b Lst \\
\hline Giga & $1 \times 2$ & & 51b Dst \\
\hline Giga & $1 \times 2$ & Ix 2.2 & $8 a$ Mdst \\
\hline Giga & Ix 2 & IX 2.2 & 31a Mdst \\
\hline Krot & $1 \times 2$ & Ix 2.2 & 32a Slst \\
\hline Lati & Ix 2 & & 16a Mdst \\
\hline Lati & Ix 2 & & 39a Lst \\
\hline Lati & $1 \times 2$ & & 42b CMdst \\
\hline Lati & $1 \times 2$ & Ix 2.3 & 3a Sst \\
\hline Lati & $1 \times 2$ & Ix 2.3 & 28b CMdst \\
\hline Ling & $1 \times 2$ & IX 2.3 & 58a Lst \\
\hline Ling & $1 \times 2$ & Ix 2.3 & $37 a$ Lst \\
\hline Ling & $1 \times 2$ & & 61a Mdst \\
\hline Ling & Ix 2 & Ix 2.4 & 16b CMdst \\
\hline Lira & Ix 2 & IX 2.4 & 59a Lst \\
\hline Mart & $1 \times 2$ & Ix 2.4 & 41b Lst \\
\hline Mart & $1 \times 2$ & & 18a Lst \\
\hline Orbi & $1 \times 2$ & Ix 2.5 & 27a Mdst \\
\hline Orbi & Ix 2 & IX 2.5 & 30b Lst \\
\hline Orbi & $1 \times 2$ & IX 2.5 & 40a Lst \\
\hline orth & $1 \times 2$ & $1 \times 2.5$ & 38a CMdst \\
\hline orth & $1 \times 2$ & Ix 2.6 & 4b Slst \\
\hline orth & $1 \times 2$ & Ix 2.6 & 60a Lst \\
\hline Phri & $1 \times 2$ & Ix 2.6 & 27b MLst \\
\hline Phri & Ix 2 & Ix 2.6 & 31b CMdst \\
\hline Phri & $1 \times 2$ & IX 2.6 & 8b Lst \\
\hline Phri & $1 \times 2$ & Ix 2.6 & 33b Slst \\
\hline Phri & Ix 2 & Ix 2.6 & 43b Mdst \\
\hline Pleu & $1 \times 2$ & Ix 2.6 & 53a MLst \\
\hline Pleu & $1 \times 2$ & Ix 2.6 & 19b Slst \\
\hline Prod & $1 \times 2$ & Ix 2.6 & 51a Lst \\
\hline Prod & & & 32b Mdst \\
\hline Prod & & & $2 a$ Sst \\
\hline Prod & & & 32c Lst \\
\hline Prod & & & 56a Mdst \\
\hline Prod & & & \\
\hline Pugi & & & \\
\hline
\end{tabular}


Pugn

Pugn

Punc

Pust

Pust

Rhip

Rhip

rhyn

Rugo

Rugo

Sche

Sche

Sche

Schi

Schi

Schi

Schi

SPI1

SPI1

SPI2

SPI3

SPI4

spir

Sten

Sten

brac

Bell

Bell

bell

Dona

Euph

Euph

Euph

Euph

Glab

Loxo

loxo

Meek

Nati

pleu

Porc

Reti

Reti

Reti

Reti

Sole

Stra

pupa

pupa 
Dent

Dent

Acti

Anth

Anth

Anth

Avic

Avic

Card

Edmo

Edmo

Edmo

Edmo

Edmo

Edmo

Euch

Euch

Leio

Leio

Lith

Lith

Myal

Myal

Myal

Nucu

nucu

PALE

PALE

PALE

Para

pect

Phes

Posi

Posi

Posi

Posi

Prom

Prot

Sagu

Sang

Sang

Sang

Sang

Sang

Sang

$\mathrm{SCH} 2$

$\mathrm{SCH} 2$

Sedg

SOLM

SOLM

Steb

Steb

Steb 
Sulc

Sulc

Sulc

Wilk

Wilk

biva

ORTH

naut

naut

naut

goni

goni

PALA

tril

tril

crus

ostr

echi

Pote

crin

PETA

fish

worm 